\title{
Removal of Some Heavy Metals From Aqueous Solution Using Biosorbent Materials and Nanoparticles
}

\author{
Doaa, A. El-Nagar ${ }^{1}$, G. Abdel-Nasser ${ }^{2}$, Thanaa I. Shalaby ${ }^{3}$, \\ Azza R. Ahmed', Wafaa H. M. Ali ${ }^{2}$ \\ ${ }^{1}$ Soil Improvement Dept., Soil, Water and Environment Institute, ARC \\ ${ }^{2}$ Soil and Agricultural Chemistry Dept., Faculty of Agriculture (Saba Basha) - \\ Alexandria University \\ ${ }^{3}$ Medical Biophysics Dept., Medicine Research Institute, Alexandria University
}

\begin{abstract}
A batch sorption experiments were carried out to study the role of biosorbent and nano-particles on removal of some heavy metals from aqueous solution. The rice straw waste was used as biosorbent material( by-product of agricultural activity). In addition, NanoHydroxyapatite $(60 \mathrm{~nm})$ and nano-Zero Valent Iron $(25 \mathrm{~nm})$ were used as nanoparticles. The batch sorption was done using rice straw waste (RSW) with three sizes as $0.125,0.25$ and 0.5 $\mathrm{mm}$ with $\mathrm{Pb}^{2+}$ and $\mathrm{Ni}^{2+}$ with concentrations up to 28.14 and $100 \mathrm{mg} / \mathrm{l}$, respectively. Also, the sorption experiment was conducted using nano-particles (n-HAP and n-ZVI) and phosphate rock for $\mathrm{Pb}^{2+}$ and $\mathrm{Ni}^{2+}$ with concentration up to $20 \mathrm{mg} / \mathrm{l}$ for $\mathrm{Ni}$ and $18.0 \mathrm{mg} / \mathrm{l}$ for $\mathrm{Pb}$. The results indicated that RSW $(0.250 \mathrm{~mm})$ was best size for heavy metals removal. The rice straw waste has more ability for retention of heavy metals such as $\mathrm{Ni}$ and $\mathrm{Pb}$ according to linear and Freundlich sorption models. Also, the results indicated that maximum sorption capacity of heavy metals was occurred on Nano-Hydroxyapatite ( $\mathrm{n}$-HAP) for both $\mathrm{Pb}$ and $\mathrm{Ni}$. These results may be due to the functional groups found in Nano-Hydroxyapatite. When RSW mixed with n-HAP, the results indicated maximum removal percentage of heavy metals. The removal percentage of $\mathrm{Pb}(99.70 \%)$ was more than $\mathrm{Ni}(38.25 \%)$ indicated that the ability of $\mathrm{Pb}$ to bind with $\mathrm{RSW}$ or $\mathrm{n}$ HAP more than Ni. The current results are very useful in the treatment of wastewaters for the removal of heavy metals, making them suitable for agricultural purposes. The present study recommends a future studies to understand the role of nanomaterials on removal the different heavy metals under different conditions.
\end{abstract}

Keywords: heavy metals, batch sorption, biosorbents, biosorption, nano-particles, n-HAP, nZVI, phosphate rock.

\section{INTRODUCTION}

The presence of high levels of heavy metals in the environment may cause long-term health risks to humans and ecosystems. It is therefore mandatory that their levels in drinking water, wastewater and water used for agricultural and recreational purposes must be reduced to within the allowable concentrations recommended by national and international health authorities such as the World Health Organization. Adsorption is an effective physicochemical purification and separation technique used in water and wastewater treatments. It is considered as preferred method for removal, recovery and recycling of toxic heavy metals. Cost is an important parameter for comparing the sorbent materials. Biosorbent or biomaterials able for adsorption of heavy metals on their active surfaces and can be used with safe for removal of heavy metals from wastewaters up to concentration of $200 \mathrm{mg} / \mathrm{l}$.

Treatment of metal bearing industrial wastewater is of height ended interest (Pakshirajan and Swaminathan, 2009; Acheampong et al., 2013). This is mainly because heavy metals are toxic even at a very low concentration to human, animal and plant species. 
Natural wastes such as agricultural solid wastes have surface active materials can be able to remove or reduce the concentration of heavy metals from polluted ground and surface water. Natural clay and hydroxyapatite will be used also for heavy metals adsorption then; the treated water can be used for irrigation purposes.

Amongst the different known techniques to remove heavy metals from wastewater, biosorption seems to be cost effective as it involves only a passive process for heavy metal sequestration by using mostly dead/inactive and cheap biomass (Nadeem et al., 2014). Also, among the different biomass types available for heavy metal removal, the cyanobacterial biomass is particularly attractive owing to its complex biomass structure, minimum nutrient requirement, abundant growth within a short time period, ability to grow well under environmentally stressed conditions etc. The use of dead cyanobacterial biomass is also advantageous because it doesn't require any kind of special media for its growth (Gupta and Rastogi, 2008). Further, it has been reported that chemical pretreatment of such biosorbents show a large ability to form complex with metal ions, thus aiding in their efficient removal from aqueous solution (Afkhami et al., 2007).

Industrial heavy metal pollution has become a serious environmental and sanitary problem all over the world in recent years. Heavy metals can not only have toxic and harmful effects on organisms living in water, but also accumulate throughout the food chain and may also affect human beings (Martins et al., 2004; Sari and Tuzen, 2008). Heavy metals such as cadmium, lead and nickel among others, are commonly detected in industrial effluents. A variety of syndromes, renal function hypertension, hepatic injury, lung damage and teratogenic effects may result from cadmium toxicity (Sari et al., 2008). Lead may cause mental disturbance, retardation, and semi-permanent brain damage (Paulino et al., 2008). The occurrence of heavy metals especially cadmium and nickel in industrial effluents beyond permissible limits brings serious environmental pollution, threatening human health and ecosystem. Therefore, these pollutions must be removed to an acceptable level before being released into water ecosystem.

Many techniques, such as ion exchange, precipitation, adsorption, membrane processes, reverse osmosis, sedimentation, electro-dialysis, etc., have been employed for separation of heavy metals from wastewater (PerezQuintanillo et al., 2007; Amini et al., 2009). With the increase in environmental pollution, there is a growing demand to develop new adsorbents of higher efficiency for heavy metal ions removal from aqueous media than those commercially available (Matlock et al., 2002).

The present study adopts a non-expensive and safe technology for removal of heavy metals from industrial wastewater using biosorbents and nanoparticles. 


\section{MATERIALS AND METHODS \\ Biosorbent}

Rice straw waste (RSW) was collected from an agricultural farm in Damnhour, El-Beharia Governorate. The RSW was ground to powder and was sieved with three different sized meshes to obtain three different grade particle sizes namely; $0.125 \mathrm{~mm}, 0.125-0.25 \mathrm{~mm}$, and $0.25-0.5 \mathrm{~mm}$. The properties of the used rice straw are presented in Table (1).

\section{Nanoparticles}

Zero valent Iron nanoparticle ( $\mathrm{n}-\mathrm{ZVI})$, consisting of $\mathrm{Fe}(0)$ surface stabilized nanoparticles, 98\% Pure, APS: $25 \mathrm{~nm}$ and hydroxyapatite nanoparticles (n-HAP), $\mathrm{Ca}_{10}\left(\mathrm{PO}_{4}\right)_{6}(\mathrm{OH})_{2}$, Calcium phosphate tribasic, $96 \%$ Pure, APS: $60 \mathrm{~nm}$ were used. Morphology: Needle like. The materials were purchased from M K Impex Corp. Division: MKnano 6382 Lisgar Drive, Mississauga, Ontario L5N 6X1, Canada. The properties of the used Zero Valent Iron nanoparticle and hydroxyapatite nanoparticles.

\section{Phosphate Rock}

The Phosphate rock crushed and passed through an $0.063 \mathrm{~mm}$ sieve. Analysis of phosphate rock was carried out according the methods described in Safi et al (2006), Hassan et al. (2013) and Aissa et al. (2014). The properties of the phosphate rock are illustrated in Table (2).

Table (1). Some chemical properties of the rice straw waste (RSW)

\begin{tabular}{ccc}
\hline Parameters & Unit & Value \\
\hline $\mathrm{pH}$ & - & 7.73 \\
$\mathrm{EC}$ & $\mathrm{dS} / \mathrm{m}$ & 7.2 \\
$\mathrm{Ni}$ & $\mathrm{mg} / \mathrm{kg}$ & 0.35 \\
$\mathrm{Co}$ & $\mathrm{mg} / \mathrm{kg}$ & 0 \\
$\mathrm{Cd}$ & $\mathrm{mg} / \mathrm{kg}$ & 0 \\
$\mathrm{~Pb}$ & $\mathrm{mg} / \mathrm{kg}$ & 3.05 \\
$\mathrm{~B}$ & $\mathrm{mg} / \mathrm{kg}$ & 21.45 \\
$\mathrm{Cu}$ & $\mathrm{mg} / \mathrm{kg}$ & 1.45 \\
$\mathrm{Zn}$ & $\mathrm{mg} / \mathrm{kg}$ & 9.75 \\
$\mathrm{Mn}$ & $\mathrm{mg} / \mathrm{kg}$ & 9.9 \\
$\mathrm{Fe}$ & $\mathrm{mg} / \mathrm{kg}$ & 87.6 \\
$\mathrm{Ca}$ & $\%$ & 0.12 \\
$\mathrm{Mg}$ & $\%$ & 0.05 \\
$\mathrm{~K}$ & $\%$ & 0.59 \\
$\mathrm{P}$ & $\%$ & 0.04 \\
$\mathrm{~N}$ & $\%$ & 0.6 \\
$\mathrm{OM}$ & $\%$ & 79.5 \\
Cellulose & $\%$ & 38.3 \\
Hemi cellulose & $\%$ & 29.7 \\
Lignin & $\%$ & 10.2 \\
Ash & $\%$ & 4.8 \\
\hline
\end{tabular}


Table (2). Some chemical properties of the phosphate rock (PR)

\begin{tabular}{cccc}
\hline Parameters & Unit & Soluble & Total \\
\hline $\mathrm{N}$ & $\%$ & 0.059 & 2.10 \\
$\mathrm{P}_{2} \mathrm{O}_{5}$ & $\%$ & 0.11 & 8.24 \\
$\mathrm{~K}_{2} \mathrm{O}$ & $\%$ & 0.02 & 0.02 \\
$\mathrm{Ca}$ & $\%$ & 0.62 & 19.30 \\
$\mathrm{Mg}$ & $\%$ & 0.03 & 0.60 \\
$\mathrm{Fe}$ & $\%$ & 0.00 & 1.10 \\
$\mathrm{Mn}$ & $\%$ & 0.07 & 0.55 \\
$\mathrm{Zn}$ & $\%$ & 0.013 & 0.35 \\
$\mathrm{Cu}$ & $\mathrm{mg} / \mathrm{kg}$ & 0.0 & 9.0 \\
$\mathrm{Ni}$ & $\mathrm{mg} / \mathrm{kg}$ & 2.5 & 23.0 \\
$\mathrm{Cd}$ & $\mathrm{mg} / \mathrm{kg}$ & 1.0 & 4.5 \\
$\mathrm{~Pb}$ & $\mathrm{mg} / \mathrm{kg}$ & 3.7 & 330 \\
$\mathrm{Co}$ & $\mathrm{mg} / \mathrm{kg}$ & 0.0 & 0.0 \\
\hline
\end{tabular}

\section{Batch experiments \\ Batch biosorption of RSW}

The stock solutions of the $\mathrm{Pb}^{2+}$ and $\mathrm{Ni}^{2+}$ used in this study was (1000 $\mathrm{mg} / \mathrm{l})$. Subsequent dilutions of $(2.94,3.53,6.81,11.92,20.88$ and $28.14 \mathrm{mg} / \mathrm{l})$ and $(2,5,10,20,50$ and $100 \mathrm{mg} / \mathrm{l})$, respectively were prepared by suitably diluting the stock solution with double distilled water. The experiments were performed in $100 \mathrm{ml}$ flasks containing $25 \mathrm{ml}$ of $\mathrm{Pb}^{2+}$ or $\mathrm{Ni}^{2+}$ of different concentration plus $0.5 \mathrm{~g}$ rice straw waste with three different sizes, and with three replicates for each experiment. The mixture was shaken in a rotary shaker at $50 \mathrm{rpm}$ for one hour followed by filtration using Whatman filter paper (No.1). The filtrate containing the residual concentration of $\mathrm{Pb}$ or $\mathrm{Ni}$ was stored for analysis.

\section{Batch nanoparticle and phosphate rock sorption}

The stock solutions of the $\mathrm{Pb}^{2+}$ and $\mathrm{Ni}^{2+}$ used in this study was (1000 $\mathrm{mg} / \mathrm{l})$. Subsequent dilutions of $(1.25,2,5,11.97,13.53$ and 18$)$ and $(1,2,5,10$, 15 and $20 \mathrm{mg} / \mathrm{l}$ ), respectively were prepared by suitably diluting stock solution with double distilled water. The experiments were performed in $100 \mathrm{ml}$ flasks containing $25 \mathrm{ml}$ of $\mathrm{Pb}^{2+}$ or $\mathrm{Ni}^{2+}$ of different concentration plus $0.1 \mathrm{~g}$ of Zero Valent Iron nanoparticle (n-ZVI), hydroxyapatite nanoparticles(n-HAP) or $0.2 \mathrm{~g}$ of phosphate rock, and with three replicates for each experiment. The mixture was shaken in a rotary shaker at $50 \mathrm{rpm}$ for one hour followed by filtration using Whatman filter paper (No.1). The filtrate containing the residual concentration of $\mathrm{Pb}$ or $\mathrm{Ni}$ was saved for analysis. 


\section{Batch sorption of hydroxyapatite nanoparticles and rice straw waste $\underline{\text { mixture }}$}

Batch equilibrium experiments were performed at room temperature in $100 \mathrm{ml}$ Erlenmeyer flasks containing $25 \mathrm{ml}$ of either $\mathrm{Pb}^{2+}$ or $\mathrm{Ni}^{2+}$ of known concentration, $20 \mathrm{mg} / \mathrm{l}$. An accurately weighed $1 \mathrm{~g}$ of rice straw, size of $0.25 \mathrm{~mm}$ and $0.1 \mathrm{~g}$ of hydroxyapatite nanoparticles was added to each flask with three replicates. The mixture was shaken in a rotary shaker at $50 \mathrm{rpm}$ for 30 minutes followed by filtration using Whatman filter paper (No.1). The filtrate containing the residual concentration of $\mathrm{Pb}$ or $\mathrm{Ni}$ was saved for analysis.

\section{Heavy metal sorption models}

According to Sethuraman and Balasubramanian (2010), the percentage of $\mathrm{Pb}^{2+}$ and $\mathrm{Ni}^{2+}$ removal was calculated using the following equation:

Removal of $\mathrm{Pb}^{2+}$ or $\mathrm{Ni}^{2+}(\%)=\frac{C_{0}-C_{e}}{C_{0}} * 100$

Where, Co and Ce represent initial and equilibrium concentrations of $\mathrm{Pb}^{2+}$ and $\mathrm{Ni}^{2+}$.

According to (Vieira and Volesky, 2003; Vijayaraghavan et al., 2006) the equilibrium sorption capacity of $\mathrm{Pb}^{2+}$ or $\mathrm{Ni}^{2+}$ was calculated using the following equation:

$$
S=\frac{\left(C_{0}-C_{e}\right) \times V}{m}
$$

Where;

$\mathrm{S}=$ equilibrium $\mathrm{Pb}^{2+}$ or $\mathrm{Ni}^{2+}$ ions capacity $(\mathrm{mg} / \mathrm{g})$,

$\mathrm{V}=$ suspension volume $(\mathrm{I})$,

$\mathrm{m}=$ mass of pomelo material $(\mathrm{g})$,

$\mathrm{C}_{\mathrm{e}}=\mathrm{Pb}^{2+}$ or $\mathrm{Ni}^{2+}$ ions concentration at equilibrium $(\mathrm{mg} / \mathrm{l})$, and

$\mathrm{C}_{0}=$ initial ions concentration $(\mathrm{mg} / \mathrm{l})$

To study and compare the sorption of aqueous $\mathrm{Ni}$ and $\mathrm{Pb}$ on rice straw waste, n-HAP, n-ZVI and phosphate rock, the sorption data were fitted to some sorption models such as linear and Freundlich isotherm models using software IsoFit (Matott, 2007).

\section{Linear isotherm model}

$\mathrm{S}=\mathrm{K}_{\mathrm{d}} \times \mathrm{C}_{\mathrm{e}}$

\section{Freundlich Isotherm model}

$\mathrm{S}=\mathrm{K}_{\mathrm{f}} \times \mathrm{Ce}^{1 / \mathrm{n}}$

Where:

$\mathrm{K}_{\mathrm{d}}$ : partition parameter $(\mathrm{L} / \mathrm{kg})$,

$\mathrm{C}_{\mathrm{e}}$ : equilibrium concentration $(\mathrm{mg} / \mathrm{l})$

$\mathrm{K}_{\mathrm{f}}$ : Freundlich isotherm parameter, $\left.((\mathrm{mg} / \mathrm{kg}) /(\mathrm{mg} / \mathrm{l}))^{(1 / \mathrm{n})}\right)$, and

$1 / n$ : Freundlich exponent (no units). 


\section{RESULTS AND DISCUSSION}

\section{Characteristics of sorbents}

The rice straw waste (RSW), nanomaterials (n-HAP and n-ZVI) and natural material (phosphate rock, PR) were subjected to analysis by Scanning electron microscopy (SEM), Fourier Transform Infrared (FTIR) and thermal analysis (TA) to study its surface texture and surface functional groups. The SEM graphs of the all materials are presented in Figures (1 to 4).

\subsection{Scanning Electron Microscopy}

SEM Images of n-HAP is presented in Figure (1), Surface morphology and the size distribution of the particles was investigated with the Scanning Electron Microscope (SU 1510) operated at 20kV, magnification x20,000. The solid samples were sprinkled on the adhesive carbon tape which is supported on a metallic disk. The sample surface images were taken at different magnifications. The scale was about $60 \mathrm{~nm}$.

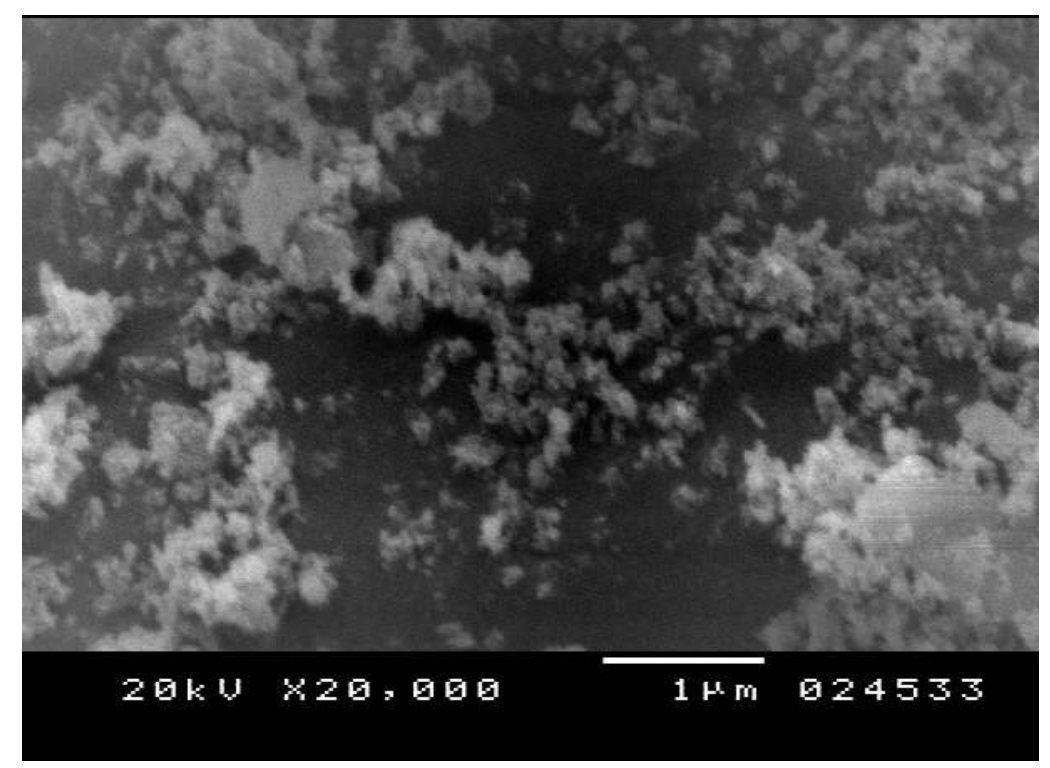

Figure (1). SEM micrograph of n-HAP particles (60 nm)

Figure 2 shows the SEM image of freshly synthesized zero valent iron nanoparticles. It can be observed that the zero valent iron nanoparticles are in the form of nanospheres, which exist in contact with each other and form chains having diameters of $25 \mathrm{~nm}$. 


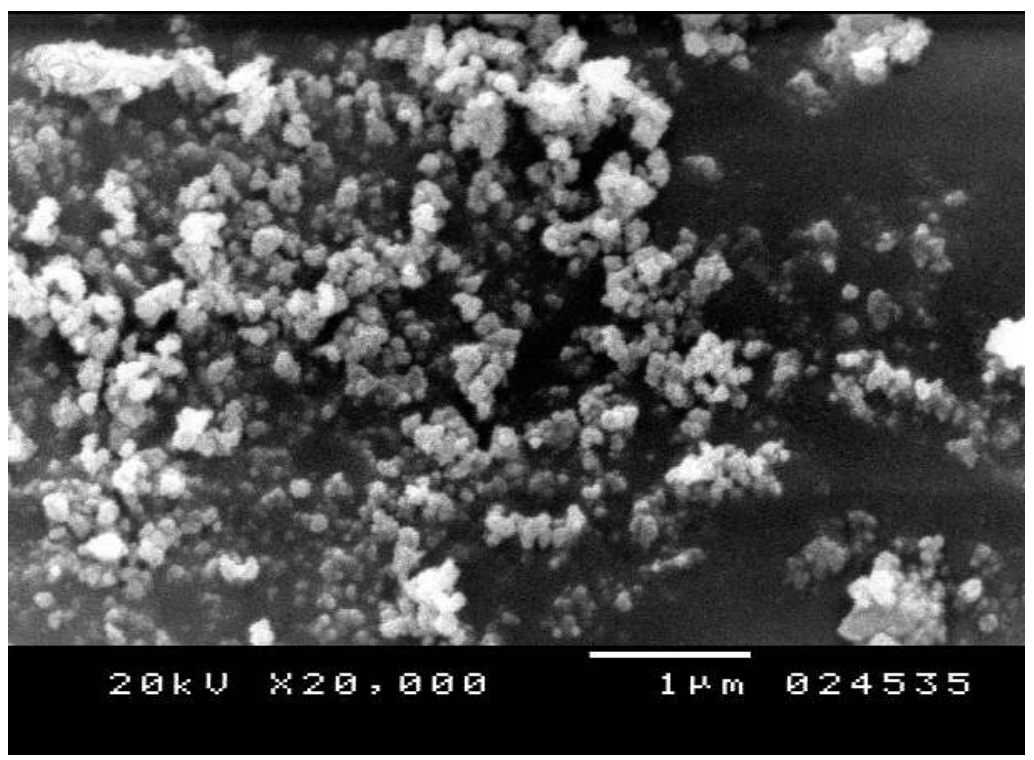

Figure (2). SEM micrograph of $\mathrm{n}$-ZVI particles $(25 \mathrm{~nm})$

SEM Images of phosphate rock particles is presented in Figure (3). The spheres having diameters of around $0.063 \mathrm{~mm}$ can be distinguished from each other and is in agreement with SEM results.

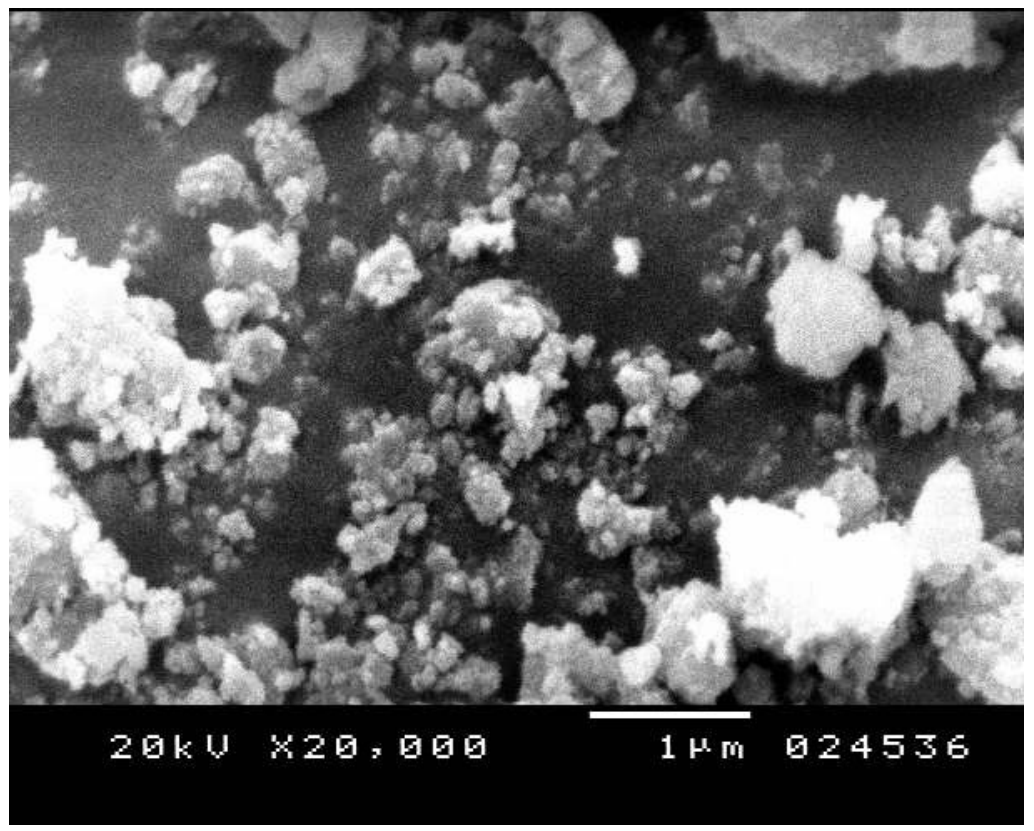

Figure (3). SEM micrograph of phosphate rock particles $(0.063 \mathrm{~mm})$

SEM Images of rice straw waste powder is presented in Figure (4). The spheres having diameters of around $0.25 \mathrm{~mm}$ can be distinguished from each other and is in agreement with SEM results. 


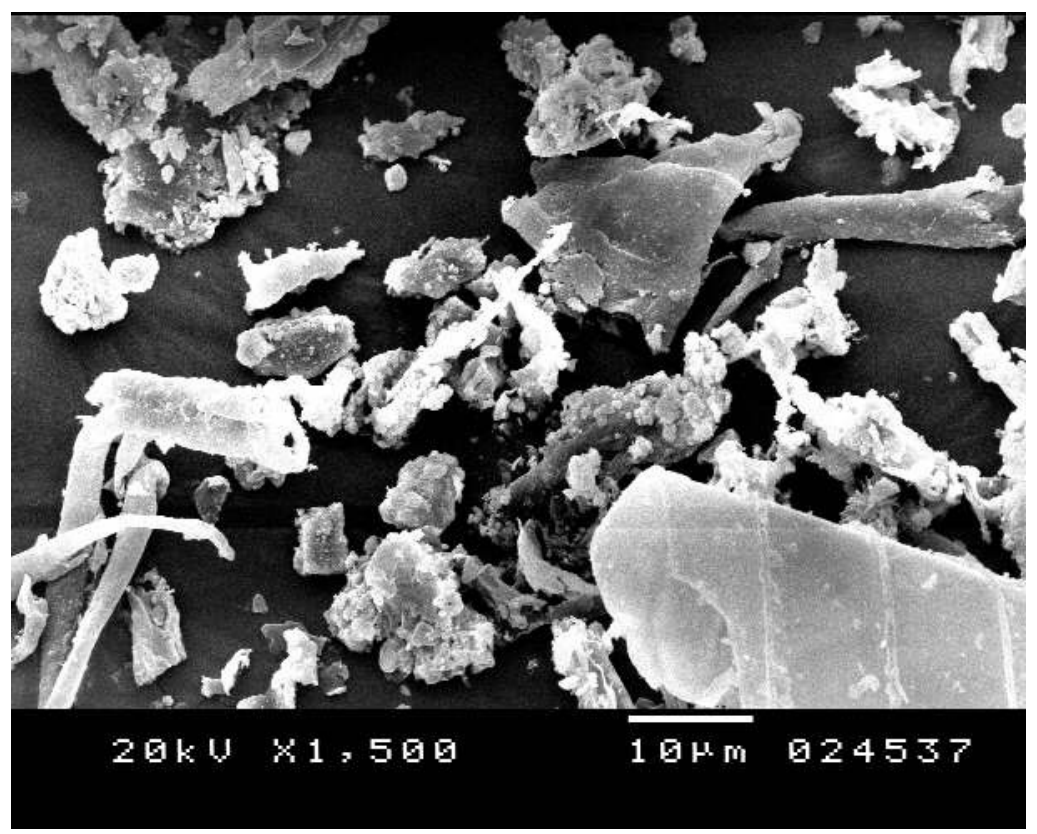

Figure (4). SEM micrograph of rice straw waste powder $(0.25 \mathrm{~mm})$

\section{2. The Fourier Transform Infrared (FTIR)}

The Fourier Transform Infrared spectra (FTIR) of rice straw waste (RSW), nanomaterials ( $\mathrm{n}-\mathrm{HAP}$ and $\mathrm{n}-\mathrm{ZVI}$ ) and natural material (phosphate rock, PR) are presented in Figures (5 to 7). Firstly, FTIR spectra of n-HAP, n-HAP particles after the sorption of aqueous $\mathrm{Ni}$ and $\mathrm{Pb}$ are illustrated in Figures $(5,6$ and 7), respectively.

As interpreted from the data of FTIR analysis, the data show the function group of n-HAP type according to wave number. The main peaks are seeing in the $n$-HAP. The functional groups were identified using the peak assignments. A strong peak at $1638.66 \mathrm{~cm}^{-1}$ was assigned to the $\mathrm{R}-\mathrm{C}^{=}-\mathrm{NR}_{2}$ stretching in $\mathrm{N}$ monosubstituted amides in solid state group.

The strong band at $1038.837 \mathrm{~cm}^{-1}$ was assigned to P-O-Alkyl stretching alkane group. The alkyl halide stretching $\mathrm{C}-\mathrm{Br}$ at $567.759 \mathrm{~cm}^{-1}$ was also observed. However, adsorption cases about $\mathrm{Ni}$ and $\mathrm{Pb}$ documented decrease in transmittance and more a symmetric stretching. It is obvious that the intensity of the peaks has increased after adsorption of $\mathrm{Ni}$ and $\mathrm{Pb}$. The intensity of the peaks has increased after adsorption of $\mathrm{Ni}$ and $\mathrm{Pb}$ in stretching vibrations of the $\mathrm{R}-\mathrm{C}^{=\mathrm{O}}-\mathrm{NR}_{2}$ at 1640.475 and $1639.336 \mathrm{~cm}^{-1}$, respectively.

The intensity of the peaks has increased after adsorption of $\mathrm{Ni}$ and $\mathrm{Pb}$ in stretching vibrations of the P-O-Alkyl at 1043.22 and $1039.899 \mathrm{~cm}^{-1}$, respectively, and stretching vibrations of the $\mathrm{C}-\mathrm{Br}$ at 568,203 and $567.927 \mathrm{~cm}^{-1}$, respectively. 


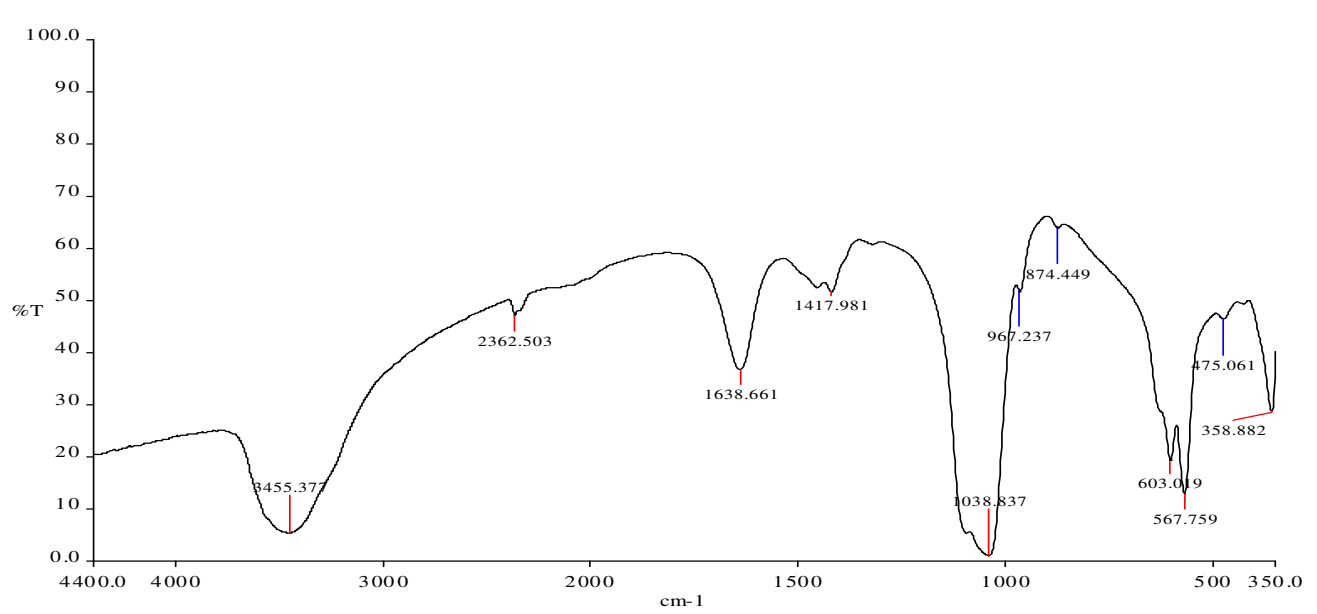

Figure (5). FTIR Spectra of n-HAP particles

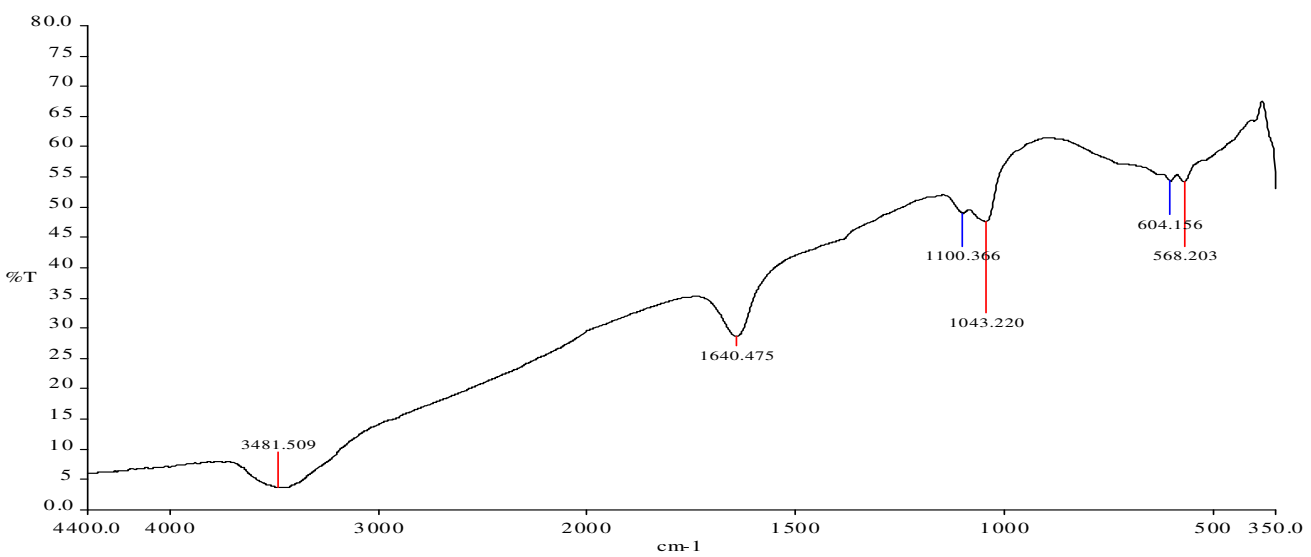

Figure (6). FTIR Spectra of n-HAP particles after the sorption of aqueous $\mathrm{Ni}$

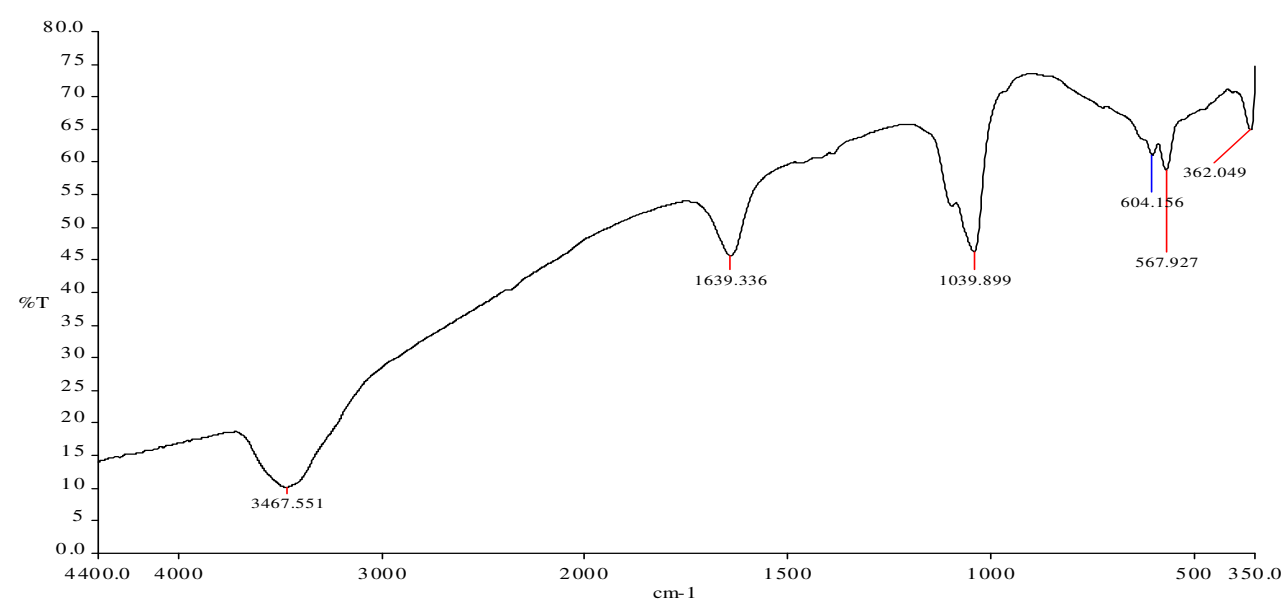

Figure (7). FTIR Spectra of n-HAP particles after the sorption of aqueous $\mathrm{Pb}$ 
The FTIR spectra of $n-Z V I, n-Z V I$ particles after the sorption of aqueous $\mathrm{Ni}$ and $\mathrm{n}-\mathrm{ZVI}$ particles after the sorption of aqueous $\mathrm{Pb}$, respectively are shown in in Figures (8, 9 and 10). As interpreted from the data of FTIR analysis, the function group of $n-Z V I$ type according to wave number. The sorption peaks at 3458.407 and $1636.48 \mathrm{~cm}^{-1}$ are ascribed to stretching vibrations of $-\mathrm{CONH}-$ groups and the $\mathrm{R}-\mathrm{C}^{=}-\mathrm{NR}_{2}$ stretching in $\mathrm{N}$-monosubstituted amides in solid state, stretching in N-N disubstituted amides, respectively. By comparing the FTIR spectra of $n-Z V I$ before and after adsorption, there were remarkable shifts in some bands. These bands are the function groups of $n-Z V I$ participate in $\mathrm{Ni}$ and $\mathrm{Pb}$ biosorption. It is obvious that the intensity of the peaks has increased after adsorption. Moreover, the wave number of the - $\mathrm{CONH}$ - was shifted from 3458.407 to $3467.397 \mathrm{~cm}^{-1}$ after the sorption of $\mathrm{Ni}$. The wave number of the CONH- was shifted from 3458.407 to $3476.189 \mathrm{~cm}^{-1}$ after the sorption of $\mathrm{Pb}$. The intensity of the peaks has increased after sorption of $\mathrm{Ni}$ or $\mathrm{Pb}$ in stretching vibrations of the $\mathrm{R}-\mathrm{C}^{=}-\mathrm{NR}_{2}$ at 1638.022 and $1637.352 \mathrm{~cm}^{-1}$, respectively.

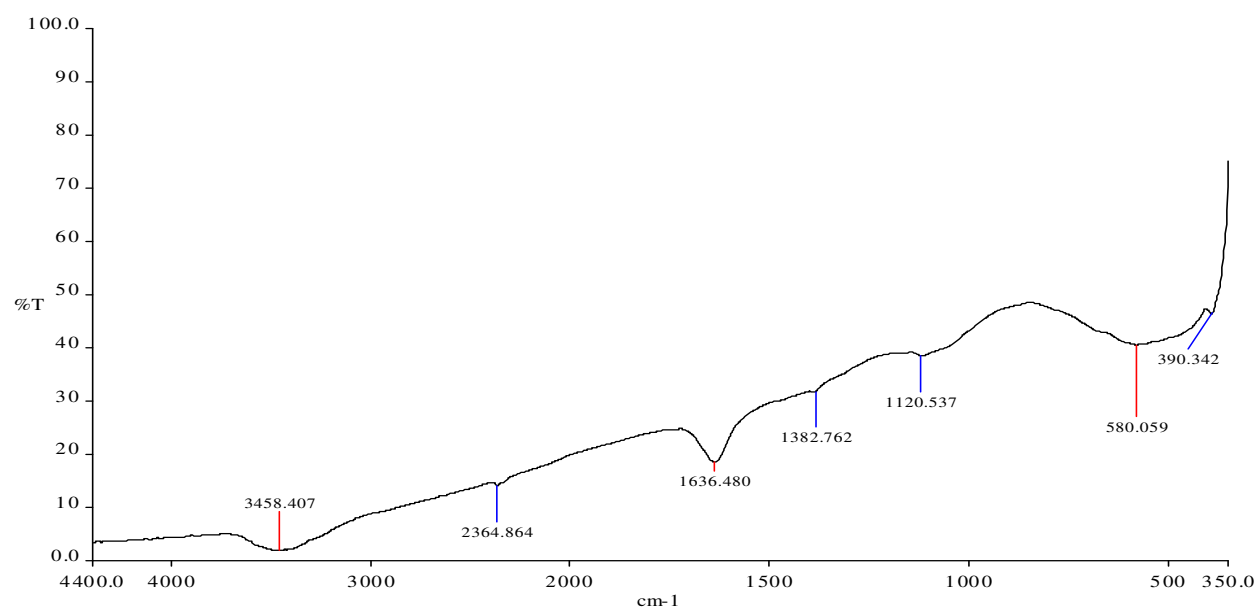

Figure (8). FTIR Spectra of n-ZVI particles

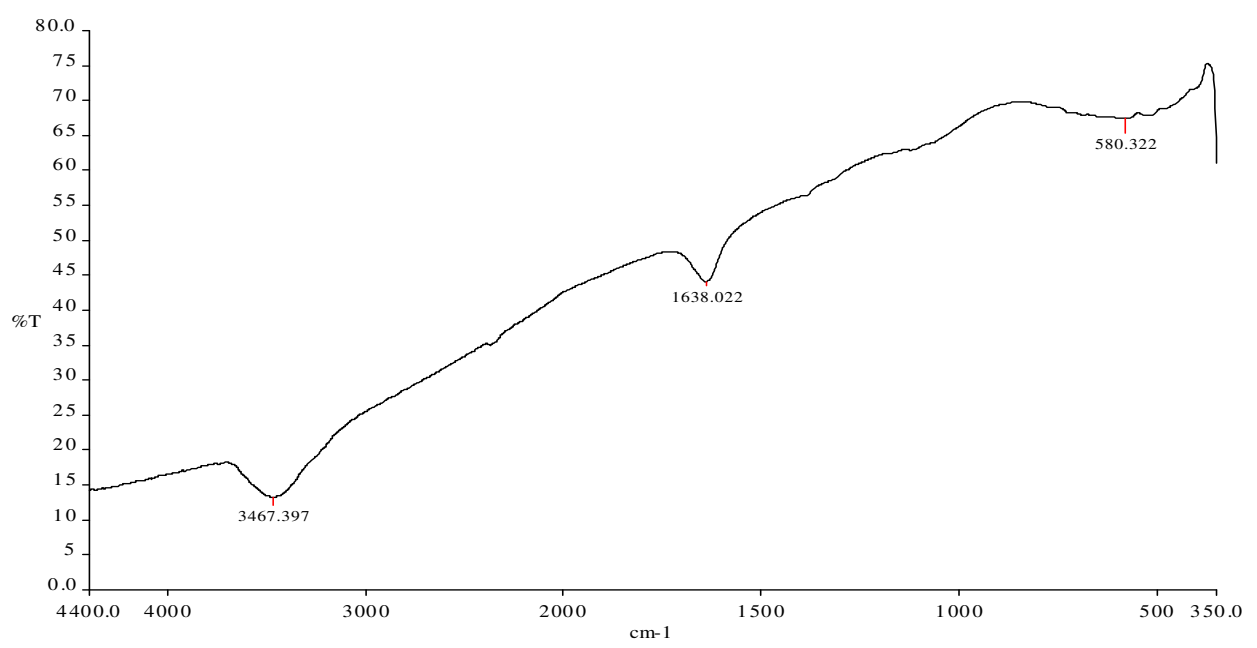

Figure (9).FTIR Spectra of n-ZVI particles after the sorption of aqueous $\mathrm{Ni}$ 


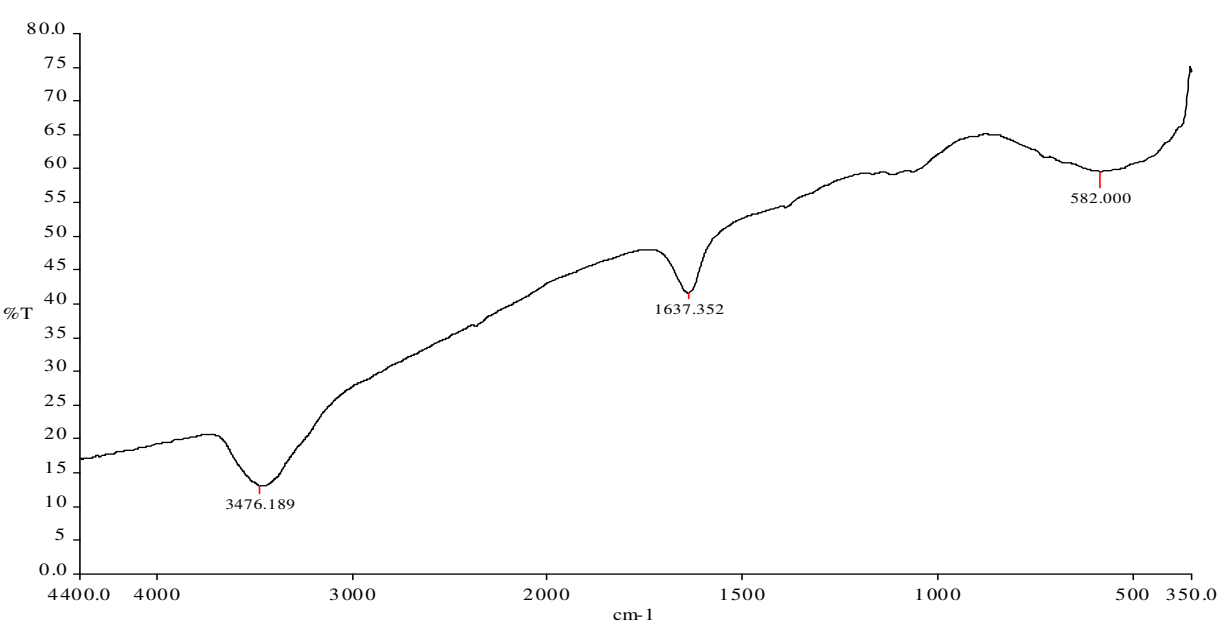

Figure (10). FTIR Spectra of $\mathrm{n}-\mathrm{ZVI}$ particles after the sorption of aqueous $\mathrm{Pb}$

FTIR spectra of phosphate rock particles, phosphate rock particles after the sorption of aqueous $\mathrm{Ni}$ and phosphate rock particles after the sorption of aqueous $\mathrm{Pb}$ are illustrated in Figures (11 to 13), respectively. As interpreted from the data of FTIR analysis, the function group of n-HAP type according to wave number, the main peaks are noticed in the phosphate rock particles. The strong bands at $3463.04,1428.878$ and $1049.536 \mathrm{~cm}^{-1}$ are due to symmetric stretching mode of $-\mathrm{CONH}-, \mathrm{RO}-\mathrm{SO} 4-\mathrm{OR}$ and $-\mathrm{C}-\mathrm{O}-\mathrm{H}$, respectively. The wave number of the $-\mathrm{CONH}$-was shifted from 3463.04 to $3451.547 \mathrm{~cm}^{-1}$ after the sorption of $\mathrm{Ni}$, and from 3463.04 to $3455 \mathrm{~cm}^{-1}$ after the sorption $\mathrm{Pb}$. The wave number of the RO-SO4-OR was shifted from 1428.878 to $1427.139 \mathrm{~cm}^{-1}$ after the sorption of $\mathrm{Ni}$, and from 1428.878 to $1423.105 \mathrm{~cm}^{-1}$ after the sorption $\mathrm{Pb}$. The wave number of the $-\mathrm{C}-\mathrm{O}-\mathrm{H}$ was shifted from 1049.536 to 1054.342 $\mathrm{cm}^{-1}$ after the sorption of $\mathrm{Ni}$, and from 1049.536 to $1048.541 \mathrm{~cm}^{-1}$ after the sorption $\mathrm{Pb}$.

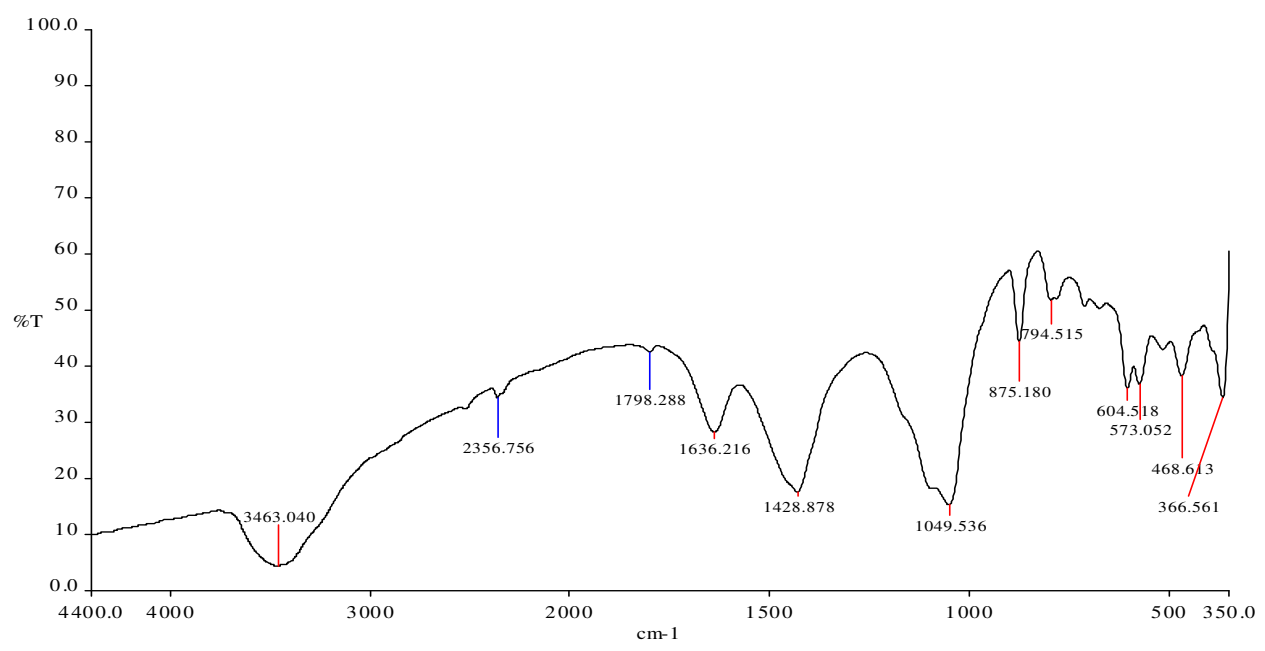

Figure (11). FTIR Spectra of phosphate rock particles 


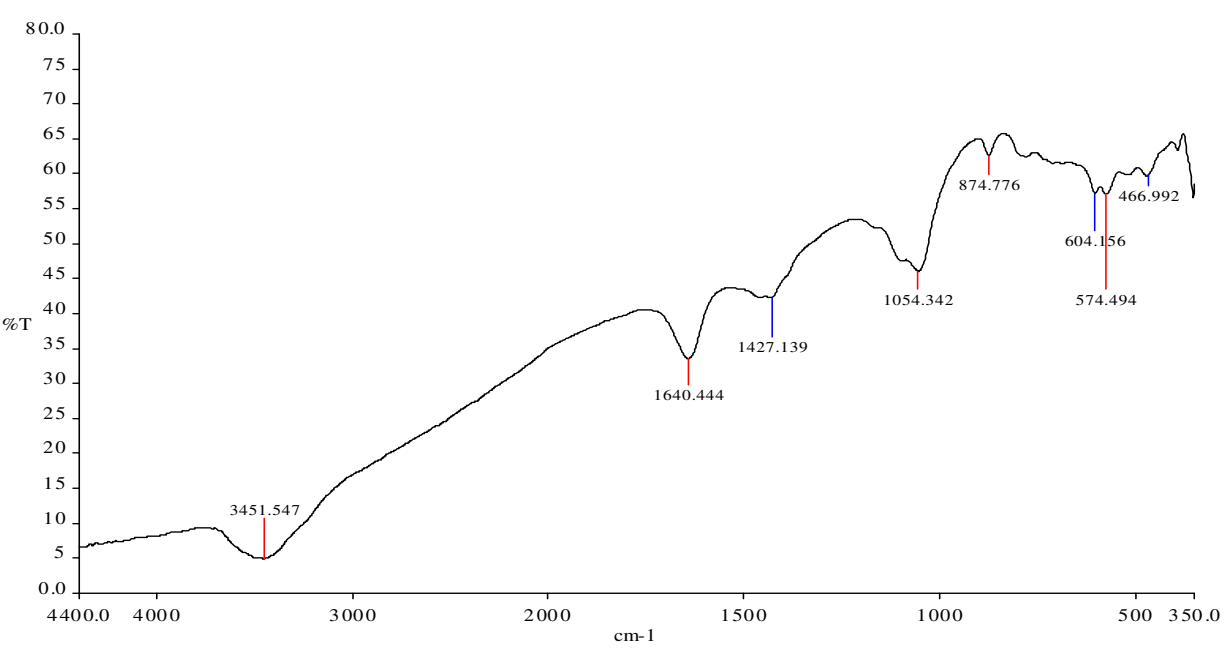

Figure (12). FTIR Spectra of phosphate rock particles after the sorption of aqueous $\mathrm{Ni}$

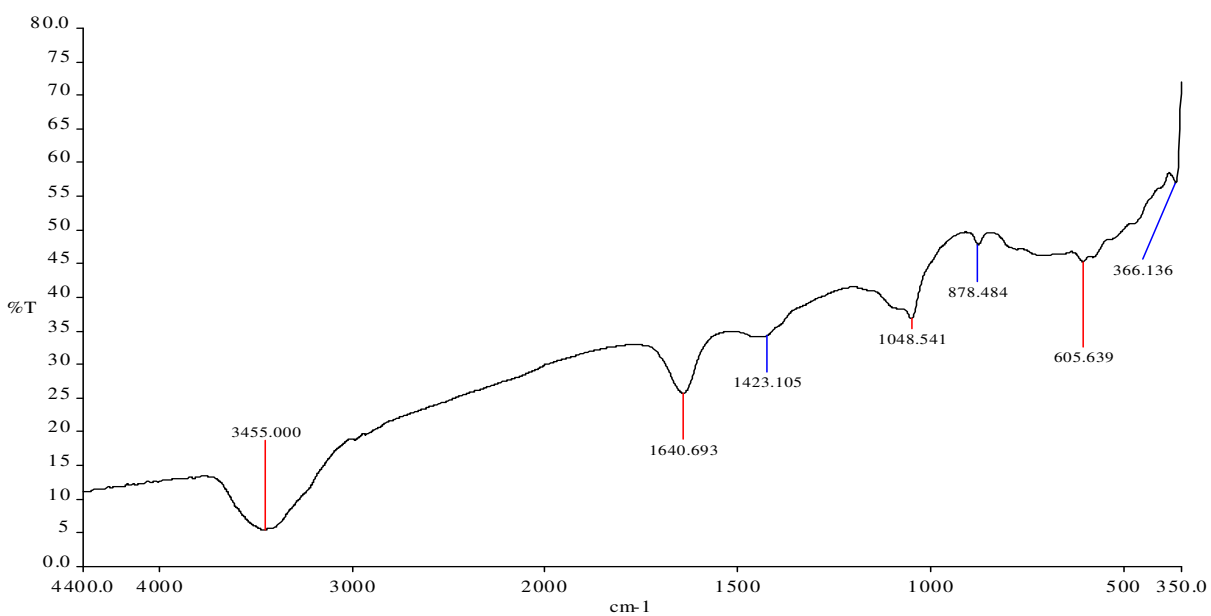

Figure (13). FTIR Spectra of phosphate rock particles after the sorption of aqueous $\mathrm{Pb}$

The Figures (14 to 16) show the FTIR spectra of rice straw waste (RSW) powder, RSW powder after the sorption of aqueous $\mathrm{Ni}$ and RSW powder particles after the sorption of aqueous $\mathrm{Pb}$, respectively. As interpreted from the data of FTIR analysis, the functional groups of RSW powder were sorted according to wave number. The main peaks are noticed in the RSW powder. A strong peak at $1639.189 \mathrm{~cm}^{-1}$ was assigned to the O-amino - stretching in hydroxyarylketones groups, $\mathrm{R}-\mathrm{C}^{1 / \mathrm{O}}-\mathrm{NR}_{2}$ stretching in primary amides in solid state, the $\mathrm{R}-\mathrm{C}^{=\mathrm{O}}-\mathrm{NR}_{2}$ stretching in $\mathrm{N}$-mono-substituted amides in solid state, stretching in N-N di-substituted Amides, $-\mathrm{C}=\mathrm{C}^{\prime \mathrm{C}=\mathrm{O}}$ and $-\mathrm{O}-\mathrm{NO}_{2}$. By comparing the FTIR spectra of RSW powder before and after sorption, there were remarkable shifts in some bands. These bands are the function groups of RSW powder in $\mathrm{Ni}$ and $\mathrm{Pb}$ biosorption. It is obvious that the intensity of the peaks has increased after sorption. Moreover, the wave number was increased from $1639.189 \mathrm{~cm}^{-1}$ to $1641.451 \mathrm{~cm}^{-1}$ after the sorption Ni. Also. the wave number of the -CONH- was shifted from 1639.189 to $1640.27 \mathrm{~cm}^{-1}$ after the sorption of $\mathrm{Pb}$. 


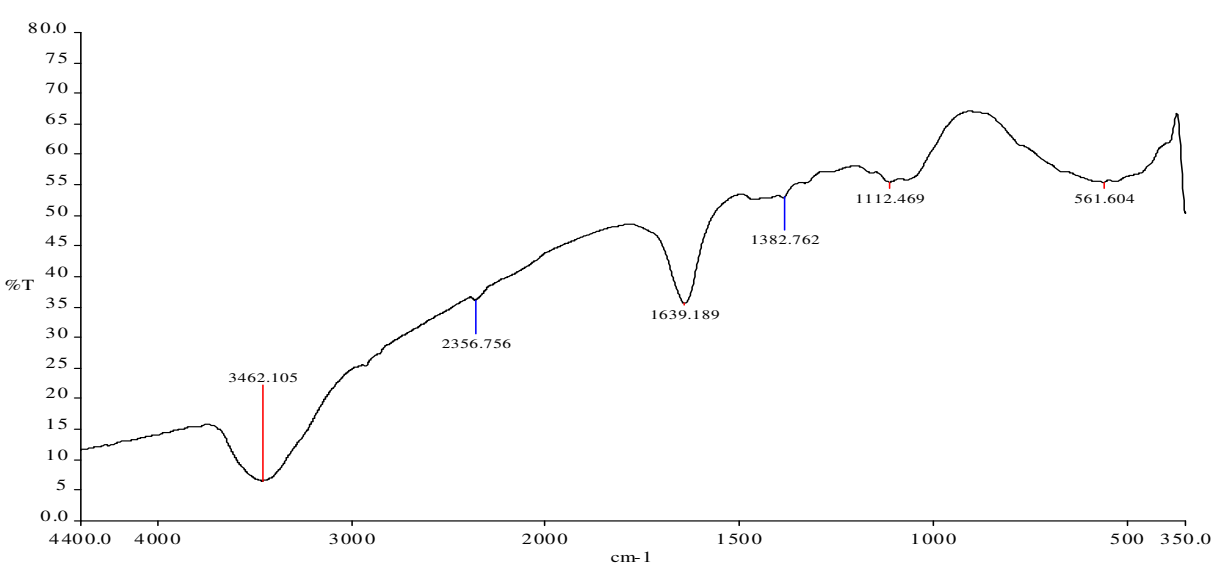

Figure (14). FTIR Spectra of rice straw waste (RSW) powder

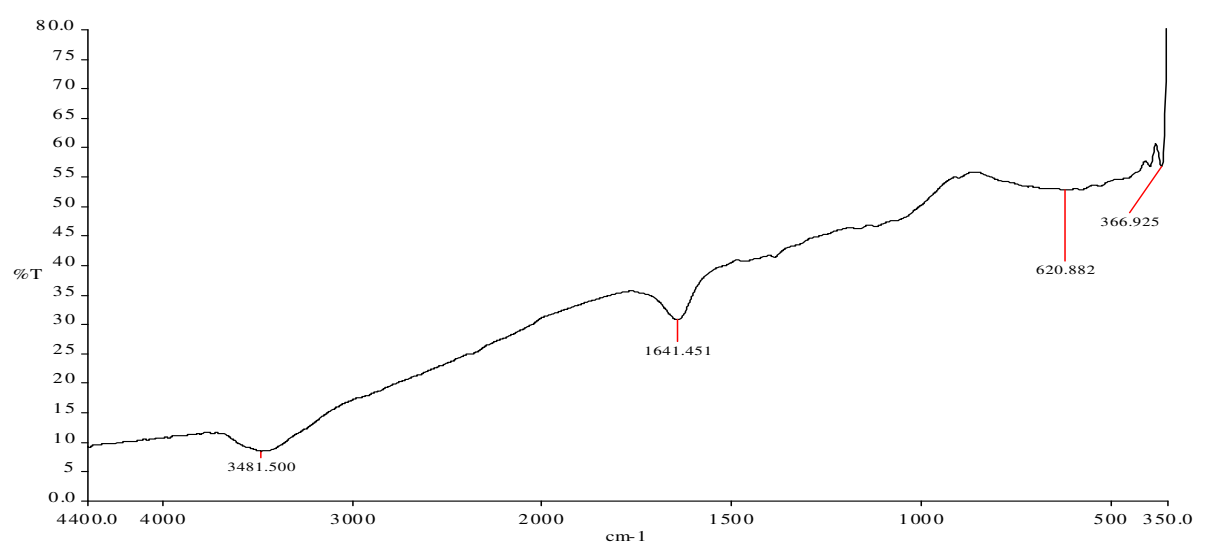

Figure (15). FTIR Spectra of rice straw waste particles after the sorption of aqueous $\mathrm{Ni}$

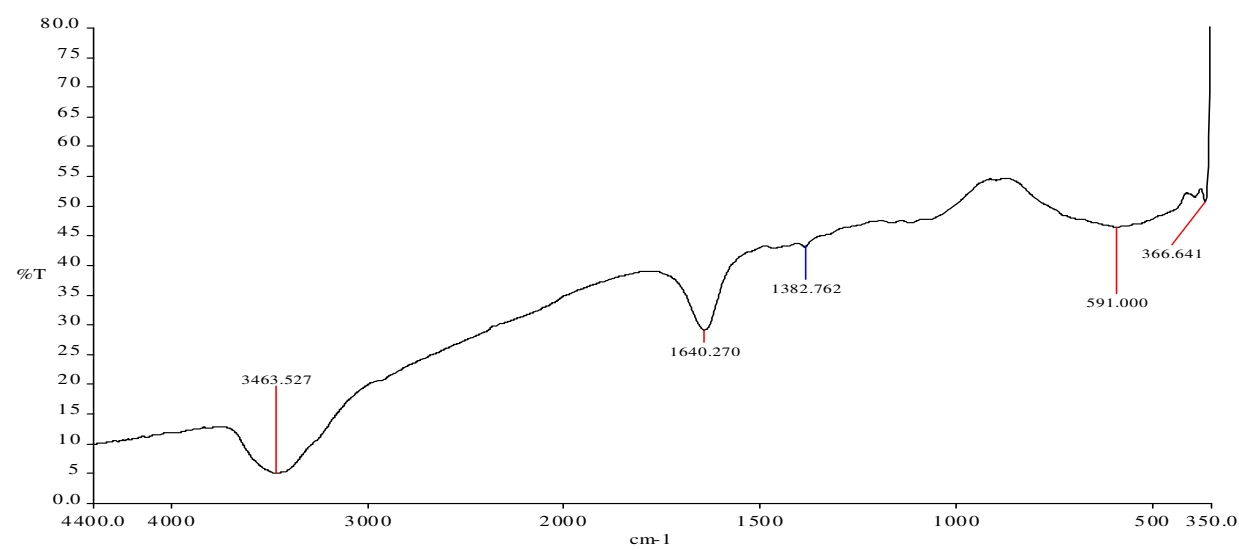

Figure (16). FTIR Spectra of rice straw waste particles after the sorption of aqueous $\mathrm{Pb}$ 


\subsection{X-ray analysis}

X-ray analysis graphs of the n-HAP are presented in Figure (17). A broad single peak was observed in the X-Ray diffraction spectrum of raw bone at $2 \theta$ of $32.7^{\circ}$, confirming that the n-HAP is amorphous.

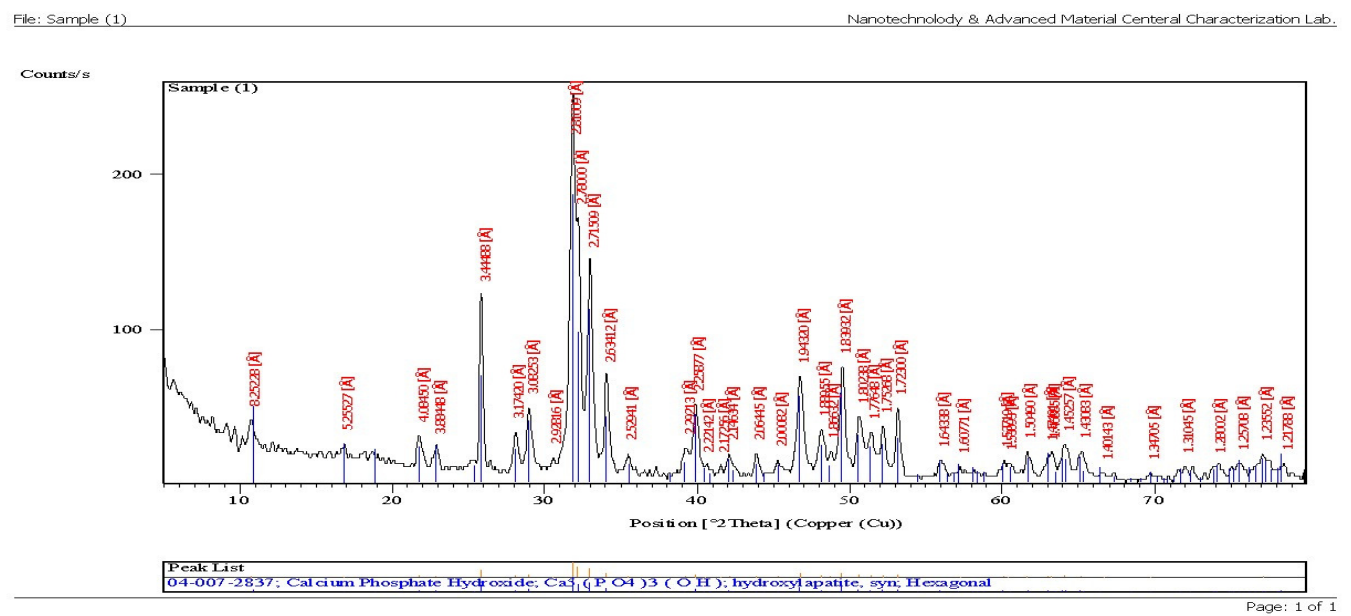

Figure (17). X-ray analysis graph of $\mathbf{n}$-HAP particles

$\mathrm{X}$-ray analysis graphs of the $\mathrm{n}-\mathrm{ZVI}$ are presented in Figure (18). The peak at $2 \theta$ of $44.25^{\circ}$ indicates the presence of $n-Z V I$ nanoparticles.

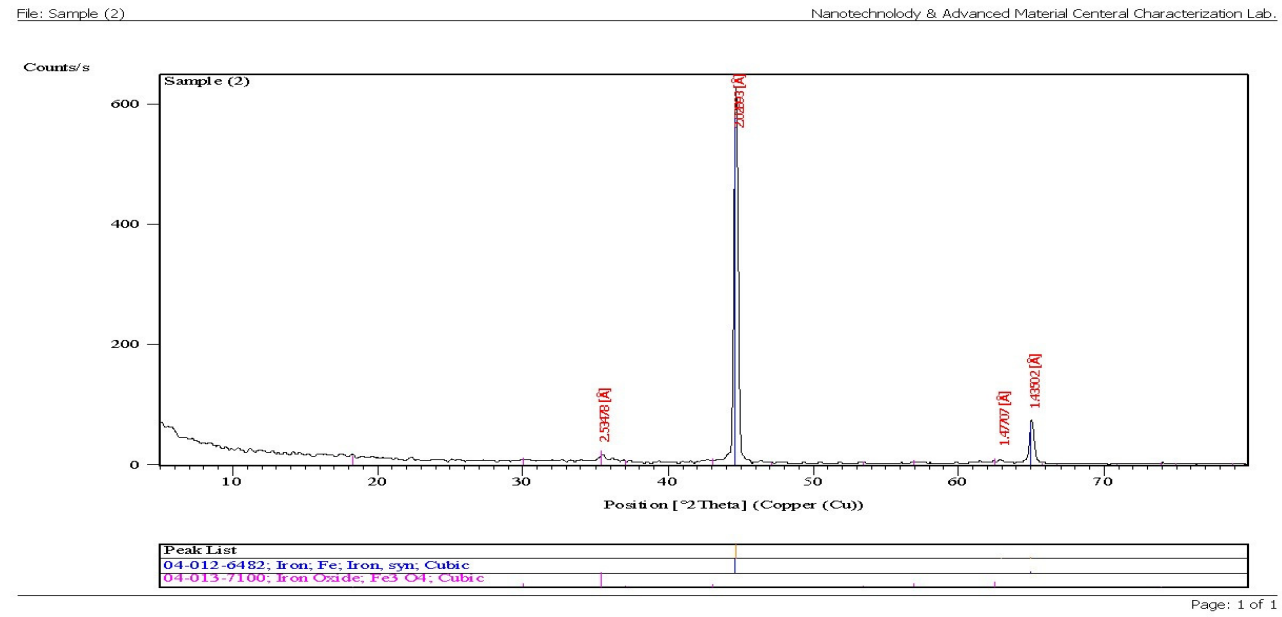

Figure 18. X-ray analysis graph of $n-Z V I$ particles

The diffract gram, presented in Figure 19, shows that phosphate rock was composed of different phases with different intensities. For each sample, the quantitative analysis of its diffract gram using MATCH program reveals the presence of the following phases: calcium carbonate phosphate $\mathrm{Ca}_{5}\left(\mathrm{PO}_{4}\right)_{3}\left(\mathrm{CO}_{3}\right)\left(2 \theta: 32.10^{\circ} ; 33.24^{\circ} ; 33.87^{\circ} ; 46.96^{\circ} ; 49.57\right)$, calcite $\mathrm{CaCO}_{3}(2 \theta$ : $\left.29.42^{\circ} ; 35.99^{\circ} ; 39.43^{\circ}\right)$, dolomite $\mathrm{Ca} \mathrm{Mg}\left(\mathrm{CO}_{3}\right)_{2}\left(2 \theta: 30.96^{\circ} ; 41.17^{\circ}\right)$ and quartz $\mathrm{SiO}_{2}\left(-; 2 \theta: 26.65^{\circ} ; 40.17^{\circ}\right)$. It appears that the recorded dolomite, calcite and quartz phases due to their nature exogangue, while the interference of these phases with fluorapatite are due to their natural endogangue. 


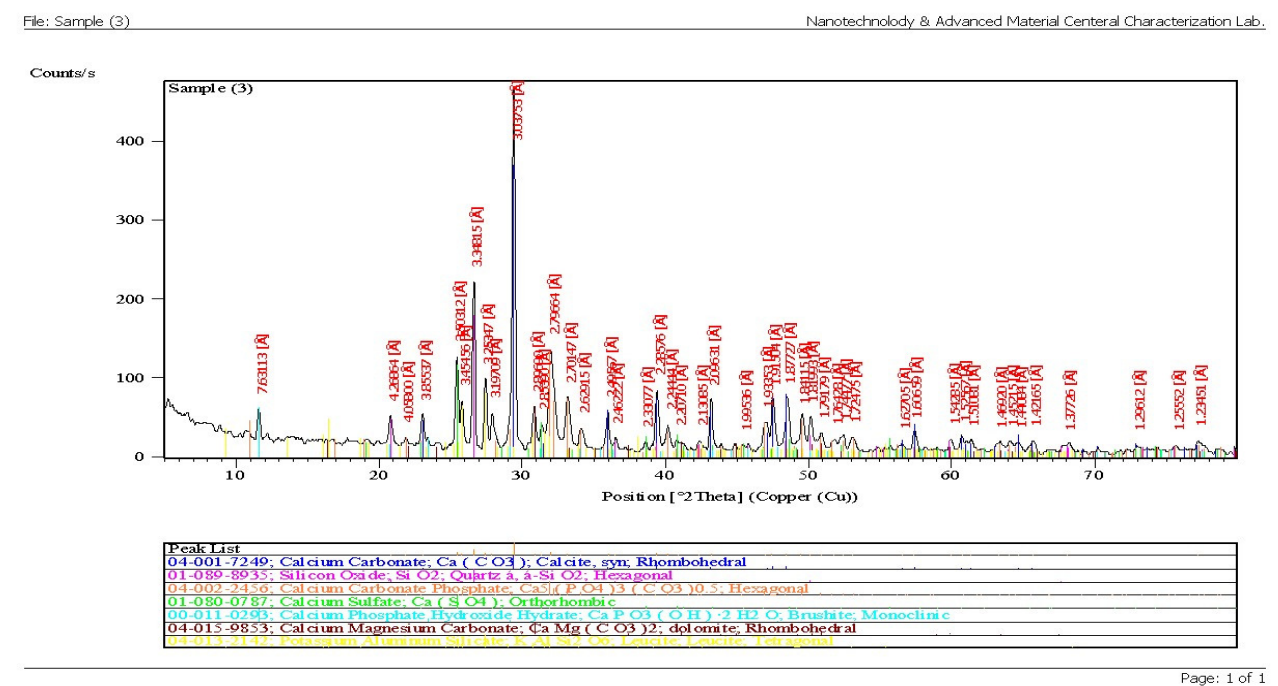

Figure (19). X-ray analysis graph of phosphate rock (PR) particles

\section{Batch sorption of rice straw waste (RSW)}

Biosorption capacity of rice straw waste (RSW) with three different sizes $(0.125,0.25$ and $0.5 \mathrm{~mm})$ increased with an increase in the initial concentration of $\mathrm{Pb}$ and $\mathrm{Ni}$ as shown in Tables (3 and 4). It suggested that the biosorption capacity of $\mathrm{Ni}$ (at $100 \mathrm{mg} / \mathrm{l})$ increased with decreasing the particle size of RSW $(0.125,0.25$ and $0.5 \mathrm{~mm})$. It is account as $2840.5,2826.0$ and $2749.5 \mathrm{mg} / \mathrm{kg}$, respectively. The biosorption capacity (S) of $\mathrm{Pb}$ (at $28.14 \mathrm{mg} / \mathrm{l})$ in rice straw with three different sizes $(0.125,0.25$ and $0.5 \mathrm{~mm})$ were $1160.3,1179.75$ and $1157.0 \mathrm{mg} / \mathrm{kg}$, respectively. The results indicated that optimum size of rice straw waste is $0.25 \mathrm{~mm}$ for maximum sorption of both $\mathrm{Pb}$ and $\mathrm{Ni}$. These results may be due to the functional groups present on their cell wall offer certain forces of attractions for the metal ions and provide a high efficiency for their removal in RSW.

Similar results have been reported by Suemitsu et al. (1986); Wong et al. (2003) and El-Sayed et al. (2010). Rice straw waste possesses high oxygen; which is largely fixed in hydroxyl group of polysaccharides. These groups help in biosorption process by making a complex between metal ions (present in aqueous solutions) and oxygen of hydroxyl group (Hafiza et al., 2010). The low particle size, have more surface area which plays an important role in the sorption process (Hayam, 2015). The adsorption capacity and the heavy metal efficiency are enhanced with the increase in the surface area because of the functional groups carboxylic groups responsible for the chelation of heavy metals. 
Table (3). Equilibrium concentration (mg/l) of Ni at different sizes of RSW

\begin{tabular}{|c|c|c|c|c|c|c|}
\hline \multirow[b]{2}{*}{$\begin{array}{c}\text { Concentration } \\
\left(C_{0}\right) \mathrm{mg} / \mathrm{l}\end{array}$} & \multicolumn{2}{|c|}{$0.5 \mathrm{~mm}$} & \multicolumn{2}{|c|}{$0.25 \mathrm{~mm}$} & \multicolumn{2}{|c|}{$0.125 \mathrm{~mm}$} \\
\hline & $\begin{array}{c}\mathrm{Ce} \\
\mathrm{mg} / \mathrm{l}\end{array}$ & $\begin{array}{c}\mathrm{S} \\
\mathrm{mg} / \mathrm{kg}\end{array}$ & $\begin{array}{c}\mathrm{Ce} \\
\mathrm{mg} / \mathrm{l}\end{array}$ & $\begin{array}{c}\mathrm{S} \\
\mathrm{mg} / \mathrm{kg}\end{array}$ & $\begin{array}{c}\mathrm{Ce} \\
\mathrm{mg} / \mathrm{l}\end{array}$ & $\begin{array}{c}\mathrm{S} \\
\mathrm{mg} / \mathrm{kg}\end{array}$ \\
\hline 0.0 & 0.0 & 0.0 & 0.0 & 0.0 & 0.0 & 0.0 \\
\hline 2.0 & 1.5 & 25.6 & 1.3 & 33.6 & 1.1 & 44.3 \\
\hline 5.0 & 2.5 & 125.6 & 2.4 & 131.5 & 3.0 & 102.5 \\
\hline 10.0 & 5.6 & 220.8 & 5.3 & 237.4 & 4.2 & 290.6 \\
\hline 20.0 & 11.0 & 450.0 & 10.9 & 398.5 & 10.8 & 461.0 \\
\hline 50.0 & 28.4 & 1079.3 & 20.0 & 1075.5 & 22.8 & 1494.0 \\
\hline 100.0 & 45.0 & 2749.5 & 43.5 & 2826.0 & 40.0 & 2840.5 \\
\hline $\begin{array}{l}\text { Average } \\
\text { removal \% }\end{array}$ & 43.86 & & 49.29 & & 49.69 & \\
\hline
\end{tabular}

Table (4). Equilibrium concentration (mg/l) of $\mathrm{Pb}$ at different sizes of RSW

\begin{tabular}{|c|c|c|c|c|c|c|}
\hline \multirow[b]{2}{*}{$\begin{array}{l}\text { Concentration } \\
\left(C_{0}\right) \mathrm{mg} / \mathrm{l}\end{array}$} & \multicolumn{2}{|c|}{$0.5 \mathrm{~mm}$} & \multicolumn{2}{|c|}{$0.25 \mathrm{~mm}$} & \multicolumn{2}{|c|}{$0.125 \mathrm{~mm}$} \\
\hline & $\begin{array}{c}\mathrm{Ce} \\
\mathrm{mg} / \mathrm{l}\end{array}$ & $\begin{array}{c}\mathrm{S} \\
\mathrm{mg} / \mathrm{kg}\end{array}$ & $\begin{array}{c}\mathrm{Ce} \\
\mathrm{mg} / \mathrm{l}\end{array}$ & $\begin{array}{c}\mathrm{S} \\
\mathrm{mg} / \mathrm{kg}\end{array}$ & $\begin{array}{c}\mathrm{Ce} \\
\mathrm{mg} / \mathrm{l}\end{array}$ & $\begin{array}{c}\mathrm{S} \\
\mathrm{mg} / \mathrm{kg}\end{array}$ \\
\hline 0.00 & 0.00 & 0.00 & 0.00 & 0.00 & 0.00 & 0.00 \\
\hline 2.94 & 0.34 & 130.09 & 0.31 & 131.79 & 0.37 & 128.85 \\
\hline 3.53 & 0.45 & 153.95 & 0.58 & 147.51 & 0.67 & 143.13 \\
\hline 6.81 & 0.76 & 302.35 & 0.90 & 295.35 & 0.90 & 295.35 \\
\hline 11.92 & 1.65 & 513.50 & 1.60 & 516.00 & 1.65 & 513.50 \\
\hline 20.88 & 3.55 & 866.50 & 3.10 & 888.85 & 3.06 & 891.10 \\
\hline 28.14 & 5.00 & 1157.00 & 4.55 & 1179.75 & 4.93 & 1160.30 \\
\hline $\begin{array}{l}\text { Average } \\
\text { removal \% }\end{array}$ & 85.98 & & 85.92 & & 84.91 & \\
\hline
\end{tabular}

The experimental data (sorption isotherm) of heavy metals sorption on rice straw waste were modeled using various simple adsorption models such as linear and Freundlich models and the equation parameters are presented in Table (5). 
Table (5). Parameters of some sorption isotherm models of $\mathrm{Ni}$ and $\mathrm{Pb}$ on rice straw waste

\begin{tabular}{|c|c|c|c|c|}
\hline Sorption model & Size of rice straw waste & Parameters & $\mathrm{Ni}^{2+}$ & $\mathrm{Pb}^{2+}$ \\
\hline \multirow{6}{*}{ Linear } & \multirow{2}{*}{$0.125 \mathrm{~mm}$} & $\mathrm{~K}_{\mathrm{d}}$ & 59.20 & 299.84 \\
\hline & & $R^{2}$ & 0.9987 & 0.9306 \\
\hline & \multirow{2}{*}{$0.250 \mathrm{~mm}$} & $\mathrm{~K}_{\mathrm{d}}$ & 66.50 & 322.61 \\
\hline & & $R^{2}$ & 0.9927 & 0.9571 \\
\hline & \multirow{2}{*}{$0.5 \mathrm{~mm}$} & $\mathrm{~K}_{\mathrm{d}}$ & 58.13 & 276.04 \\
\hline & & $\mathrm{R}^{2}$ & 0.9830 & 0.9926 \\
\hline \multirow{9}{*}{ Freundlich } & \multirow{3}{*}{$0.125 \mathrm{~mm}$} & $K_{f}$ & 55.47 & 302.31 \\
\hline & & $1 / n$ & 1.02 & 0.937 \\
\hline & & $\mathrm{R}^{2}$ & 0.9988 & 0.9955 \\
\hline & \multirow{3}{*}{$0.250 \mathrm{~mm}$} & $\mathrm{~K}_{\mathrm{f}}$ & 65.82 & 309.11 \\
\hline & & $1 / n$ & 1.00 & 0.896 \\
\hline & & $\mathrm{R}^{2}$ & 0.9928 & 0.9966 \\
\hline & \multirow{3}{*}{$0.500 \mathrm{~mm}$} & $K_{f}$ & 20.33 & 287.33 \\
\hline & & $1 / n$ & 1.29 & 0.967 \\
\hline & & $\mathrm{R}^{2}$ & 0.9991 & 0.9929 \\
\hline
\end{tabular}

The results indicated that the optimum size of rice straw waste is 0.25 $\mathrm{mm}$; it has maximum sorption of both $\mathrm{Ni}$ and $\mathrm{Pb}$. The rice straw waste has more ability for retention of heavy metals such as $\mathrm{Ni}$ and $\mathrm{Pb}$ according to linear and Freundlich models (Table 5). The ability of RSW for removing heavy metals such as $\mathrm{Ni}$ and $\mathrm{Pb}$ ranging from 46.86 to $49.69 \%$ for $\mathrm{Ni}$ related to $0.125,0.25$ and $0.5 \mathrm{~mm} \mathrm{RSW}$.

Effective sorption of heavy metals using agricultural products and byproducts may be documented such as modified rice husk (Lee et al., 1998 and Kumar and Bandyopadhyay, 2006), rice husk activated carbon (Guo et al., 2002) and maize husk (Jogi and Ansari, 2003). In general, an adsorbent can be termed as a low cost adsorbent if it requires little processing, is abundant in nature, or is a by-product or waste material from another industry (Khan et al., 2004).

The present results are in agreement with Aqeel et al. (2011). The removal efficiencies of lead, copper and zinc after applying low cost agricultural by-product as an adsorbent, increase as their initial concentrations in the polluted solution decrease. Khan et al. (2004) mentioned that the sorption capacity is depended on the type of the investigated period of contact adsorbent and the nature of the wastewater.

Also, natural low cost material that have been studied for the removal of heavy metals by adsorption include rice straw (Hui et al., 2008), black gram husk (Holan and Volesky, 1994), sugarcane bagasse (Volesky and Holan, 2008) and wheat bran. Rice straws proved to be the best biosorbent for $\mathrm{Pb}$ (II) and $\mathrm{Ni}(\mathrm{II})$ in aqueous solution. The biosorption characteristics fit well with Langmuir and Freundlich isotherm (Khalid et al., 2010). Also, Mathew (2008) stated that rice husk showed a maximum removal efficiency of $99.5 \%$ for $\mathrm{Ni}$ (II), $80.0 \%$ for $\mathrm{Cd}$ (II), $72.8 \%$ for $\mathrm{Cr}(\mathrm{VI}), 56.2 \%$ for $\mathrm{Cr}$ (III) and $40.0 \%$ for $\mathrm{Cu}$ (II). 
Rice straw and sugarcane bagasse are abundant agro-residues. The sugarcane bagasse is currently used as a biofuel and in the manufacture of pulp and building materials. On the other hand, open field burning of rice straw frequently causes serious air pollution (Nelson et al., 1980). Thus a new technology for utilization of these agro-residues to a more value added material should be developed. Many researchers proposed the use of lignocellulosic waste as biosorbents for the removal of heavy metal ions in waste water (Lee and Rowell, 2004).

Rice straw possesses high oxygen; which is largely fixed in hydroxyl group of polysaccharides. These groups help in biosorption process by making a complex between metal ions present in aqueous solution and oxygen of hydroxyl group( ).

Biosorption has been demonstrated as an efficient and economical method for the removal of heavy metals in wastewaters (Benguella and Benaissa, 2002). Several naturally available biomasses, such as seaweeds and wheat straw, can be used as biosorbents. Non-living microorganisms, seaweeds, crab shells and other waste biomasses have also been tested and shown as promising sources of biosorbents (Gadd, 1992; Vieira and Volesky, 2003). The availability of a biomass at a low cost is a key factor dictating its selection for a biosorption process. Biosorption was earlier considered to follow a mechanism similar to that of adsorption (Wagner, and Jula, 1981). Several governing mechanisms of metal uptake by a biomaterial have been proposed, including chemisorption, complexation, chelation of metals, ion exchange, adsorption and micro-precipitation (Volesky, 2000). The metal binding depends on the biosorbent type, the metal ion species and concentration, temperature, $\mathrm{pH}$, and ionic interference by other metal ions in the solution

\section{Batch sorption of nanoparticles and phosphate rock}

The effect of initial metal concentration $\left(\mathrm{Pb}^{+2}\right.$ and $\left.\mathrm{Ni}^{+2}\right)$ on adsorption onto biosorbents (Nano- hydroxyapatite, Nano- Zero Valente Iron and phosphate rock) are illustrated in Tables (6 and 7). The increase in biosorption capacity of Nano- Hydroxyapatite, Nano-Zero Valente Iron and phosphate rock was corresponded with increasing in the concentrations of $\mathrm{Pb}$ and $\mathrm{Ni}$ (up to 18 and $20 \mathrm{mg} / \mathrm{l}$, respectively). The maximum Biosorption capacities of $\mathrm{Pb}$ by these ingredients were 4496.3, 4017.5 and $2152.5 \mathrm{mg} / \mathrm{kg}$, respectively. The maximum Biosorption capacity of $\mathrm{Ni}^{+2}$ were $1283.5,1026.8$ and $757.1 \mathrm{mg} / \mathrm{kg}$, respectively. The results indicated that maximum sorption capacity of heavy metals was occurred on Nano-hydroxyapatite for both $\mathrm{Pb}$ and $\mathrm{Ni}$. These results may be due to the functional groups found in Nano-Hydroxyapatite. Similar results have been reported by Chen et al. (2010) and Yuan et al. (2010).

The experimental data (sorption isotherm) of heavy metals sorption on nanoparticles were modeled using various simple adsorption models such as linear and Freundlich models (Table 8). The nanoparticles used in the present study were hydroxyapatite nano-powder and Zero Valente Iron nano-powder, besides phosphate rock. 
Table (6). Equilibrium concentration $(\mathrm{mg} / \mathrm{l})$ of $\mathrm{Pb}$ at nanoparticles and phosphate rock

\begin{tabular}{ccccccc}
\hline \multirow{2}{*}{$\begin{array}{c}\text { Concentration } \\
\left(\mathbf{C}_{\mathbf{0}}\right) \mathbf{~} \mathbf{m g} / \mathbf{l}\end{array}$} & \multicolumn{2}{c}{$\begin{array}{c}\text { Nano- } \\
\text { Hydroxyapatite }\end{array}$} & \multicolumn{2}{c}{$\begin{array}{c}\text { Nano- Zero } \\
\text { Valente Iron }\end{array}$} & \multicolumn{2}{c}{ phosphate rock } \\
\cline { 2 - 7 } & $\begin{array}{c}\mathbf{C e} \\
\mathbf{m g} / \mathbf{l}\end{array}$ & $\begin{array}{c}\mathbf{S} \\
\mathbf{m g} / \mathbf{k g}\end{array}$ & $\begin{array}{c}\mathbf{C e} \\
\mathbf{~ m g / l}\end{array}$ & $\begin{array}{c}\mathbf{S} \\
\mathbf{m g} / \mathbf{k g}\end{array}$ & $\begin{array}{c}\mathbf{C e} \\
\mathbf{m g} / \mathbf{l}\end{array}$ & $\begin{array}{c}\mathbf{S} \\
\mathbf{m g} / \mathbf{k g}\end{array}$ \\
\hline 0.00 & 0.00 & 0.0 & 0.00 & 0.0 & 0.00 & 0.0 \\
1.25 & 0.02 & 308.3 & 0.06 & 297.0 & 0.12 & 141.3 \\
2.09 & 0.02 & 517.8 & 0.13 & 491.3 & 0.17 & 240.4 \\
5.01 & 0.04 & 1243.8 & 0.40 & 1152.5 & 0.30 & 588.8 \\
11.97 & 0.06 & 2977.9 & 1.10 & 2717.5 & 0.62 & 1418.8 \\
13.53 & 0.06 & 3367.1 & 1.32 & 3052.5 & 0.65 & 1610.0 \\
18.07 & 0.09 & 4496.3 & 2.00 & 4017.5 & 0.85 & 2152.5
\end{tabular}

Table (7). Equilibrium concentration $(\mathrm{mg} / \mathrm{l})$ of $\mathrm{Ni}$ at nanoparticles and phosphate rock

\begin{tabular}{ccccccc}
\hline \multirow{2}{*}{$\begin{array}{c}\text { Concentration } \\
\left(\mathbf{C}_{\mathbf{0}}\right) \mathbf{~} \mathbf{~ g} / \mathbf{l}\end{array}$} & \multicolumn{2}{c}{$\begin{array}{c}\text { Nano- } \\
\text { Hydroxyapatite }\end{array}$} & \multicolumn{2}{c}{$\begin{array}{c}\text { Nano- Zero } \\
\text { Valente Iron }\end{array}$} & \multicolumn{2}{c}{$\begin{array}{c}\text { phosphate } \\
\text { rock }\end{array}$} \\
\cline { 2 - 7 } & $\mathbf{C e}$ & $\mathbf{S g}$ & $\mathbf{C e}$ & $\mathbf{S}$ & $\mathbf{C e}$ & $\mathbf{S}$ \\
$\mathbf{m g} / \mathbf{k g}$ & $\mathbf{m g} / \mathbf{l}$ & $\mathbf{m g} / \mathbf{k g}$ & $\mathbf{m g} / \mathbf{l}$ & $\mathbf{m g} / \mathbf{k g}$ \\
\hline 0.0 & 0.0 & 0.0 & 0.0 & 0.0 & 0.0 & 0.0 \\
1 & 0.8 & 55.8 & 1.0 & 0.5 & 0.6 & 51.0 \\
2 & 1.5 & 132.1 & 1.9 & 31.5 & 1.4 & 80.9 \\
5 & 4.0 & 250.0 & 4.3 & 166.0 & 3.2 & 223.9 \\
10 & 7.6 & 605.3 & 8.0 & 500.0 & 6.9 & 385.3 \\
15 & 11.5 & 876.0 & 12.0 & 750.0 & 10.7 & 535.0 \\
20 & 14.9 & 1283.5 & 15.9 & 1026.8 & 13.9 & 757.1
\end{tabular}

Table (8). Parameters of some sorption isotherm models of heavy metals on nanoparticles and phosphate rock

\begin{tabular}{|c|c|c|c|c|}
\hline Sorption model & Nanoparticles & Parameters & $\mathbf{P b}$ & $\mathbf{N i}$ \\
\hline \multirow{6}{*}{ Linear } & \multirow{2}{*}{ Nano-Hydroxyapatite (n-HAP) } & $\mathrm{K}_{\mathrm{d}}$ & 51361.15 & 81.89 \\
\hline & & $R^{2}$ & 0.9355 & 0.9903 \\
\hline & \multirow{2}{*}{ Nano-Zero Valente Iron (n-ZVI) } & $\mathrm{K}_{\mathrm{d}}$ & 2151.16 & 62.97 \\
\hline & & $R^{2}$ & 0.9787 & 0.9767 \\
\hline & \multirow{2}{*}{ Phosphate Rock (PR) } & $\mathrm{K}_{\mathrm{d}}$ & 2421.58 & 53.86 \\
\hline & & $R^{2}$ & 0.9791 & 0.9916 \\
\hline \multirow{9}{*}{ Freundlich } & \multirow{4}{*}{ Nano-Hydroxyapatite (n-HAP) } & $K_{f}$ & 55257.6 & 94.89 \\
\hline & & $1 / n$ & 1.41 & 0.95 \\
\hline & & $\mathrm{R}^{2}$ & 0.9857 & 0.9849 \\
\hline & & $\mathrm{K}_{\mathrm{f}}$ & 2439.9 & 32.22 \\
\hline & Nano-Zero Valente Iron (n-ZVI) & $1 / n$ & 0.75 & 1.26 \\
\hline & & $\mathrm{R}^{2}$ & 0.9985 & 0.9929 \\
\hline & \multirow{3}{*}{ Phosphate Rock (PR) } & $\mathrm{K}_{\mathrm{f}}$ & 2421.58 & 67.83 \\
\hline & & $1 / n$ & 0.90 & 0.903 \\
\hline & & $\mathrm{R}^{2}$ & 0.9791 & 0.9939 \\
\hline
\end{tabular}


The results show the sorption parameters of heavy metals $\left(\mathrm{Pb}^{2+}\right.$ and $\mathrm{Ni}^{2+}$ ) on different nanoparticles indicated that maximum sorption of heavy metals was occurred on Nano- hydroxyapatite for both $\mathrm{Pb}$ and $\mathrm{Ni}$ according to linear and Freundlich sorption models (Table 8). The Nano-hydroxyapatite has more ability for retention of heavy metals such as $\mathrm{Pb}$ and $\mathrm{Ni}$. The partition coefficient was $81.89 \mathrm{~L} / \mathrm{kg}$ for $\mathrm{Ni}$ and $51361.15 \mathrm{~L} / \mathrm{kg}$ for $\mathrm{Pb}$, indicated that $\mathrm{Pb}$ is more binding on such materials than Ni. The values for $\mathrm{n}-\mathrm{ZVI}$ were 62.97 and $2151.2 \mathrm{~L} / \mathrm{kg}$, respectively. For phosphate rock the values were 53.86 and $2421.6 \mathrm{~L} / \mathrm{kg}$, respectively. The more ability of $\mathrm{n}-\mathrm{HAP}$ to retain the $\mathrm{Pb}$ than $\mathrm{Ni}$ reflected in high value of partition coefficient.

As reported by Mavropoulos et al. (2002); Nzihou and Sharrock (2002) and Mobasherpour et al. (2011), calcium hydroxyapatite (CaHAP), $\mathrm{Ca}_{10}(\mathrm{PO} 4)_{6}(\mathrm{OH})_{2}$, is used for the removal of heavy metals from contaminated soils, wastewater and fly ashes. The most important properties related to various surface characteristics of HAP, e.g., surface functional groups, acidity and basicity, surface charge, hydrophilicity, and porosity. It has been found that HAP surface possesses 2.6 groups $\mathrm{nm}^{-2}$ of $\mathrm{P}-\mathrm{OH}$ groups acting as sorption sites (Tanaka et al., 2005). The sorption properties of HAP are of great importance for both environmental processes and industrial purposes.

In general, HAP selectivity towards divalent metal cations is a result of the ion-exchange process with $\mathrm{Ca}^{2+}$ ions (Monteil Rivera and Fedoroff, 2002). Ionic radius of $\mathrm{Ni}^{2+}\left(0.72 \mathrm{~A}^{\circ}\right)$ slightly differ from that of $\mathrm{Ca}^{2+}\left(0.99 \mathrm{~A}^{\circ}\right)$, and it can substitute $\mathrm{Ca}^{2+}$ in the HAP crystal lattice. No structural changes of nano- HAP were detected by the powder X-ray diffraction analysis and FTIR of the solid residue with maximum amount of uptake capacity of $\mathrm{Ni}^{2+}$ and $\mathrm{Pb}^{2+}$. Monteil Rivera and Fedoroff (2002) reported that the reaction mechanism corresponds to equimolar exchange of nickel or lead and calcium yielding $\mathrm{Ca}_{10}$ ${ }_{x} \mathrm{Ni}_{x}\left(\mathrm{PO}_{4}\right)_{6}(\mathrm{OH})_{2}$, where $x$ can vary from 0 to 10 depending on the reaction time and experimental conditions $\mathrm{Ni}^{2+}$ or $\mathrm{Pb}^{2+}$ ions are first adsorbed on the nanoHAP surface and substitution with $\mathrm{Ca}^{2+}$ ion occurs as described by the following equations:

$\mathrm{Ca}_{10}\left(\mathrm{PO}_{4}\right)_{6}(\mathrm{OH})_{2}+x \mathrm{Ni}^{2+}$------- $\mathrm{Ca}_{10-\mathrm{x}} \mathrm{Ni}_{\mathrm{x}}\left(\mathrm{PO}_{4}\right)_{6}(\mathrm{OH})_{2}+\mathrm{xCa} \mathrm{Ca}^{2+}$

$\mathrm{Ca}_{10}\left(\mathrm{PO}_{4}\right)_{6}(\mathrm{OH})_{2}+\mathrm{xPb}^{2+}$------ $\mathrm{Ca}_{10-\mathrm{x}} \mathrm{Pb}_{\mathrm{x}}\left(\mathrm{PO}_{4}\right)_{6}(\mathrm{OH})_{2}+\mathrm{xCa} \mathrm{Ca}^{2+}$

The n-HAP is an effective adsorbent for the removal $\mathrm{Ni}^{2+}$ or $\mathrm{Pb}^{2+}$ from aqueous solutions. The results of XRD analysis and FTIR strongly support the ion exchange as a main mechanism for $\mathrm{Ni}^{2+}$ and $\mathrm{Pb}^{2+}$ removal by $\mathrm{n}-\mathrm{HAP}$. The results show that the $\mathrm{Ni}^{2+}$ or $\mathrm{Pb}^{2+}$ sorption by nanohydroxyapatite proceeds with a rapid surface complexation of the $\mathrm{Ni}^{2+}$ or $\mathrm{Pb}^{2+}$ on the $-\mathrm{POH}$ site before the formation of a compound of formula $\mathrm{Ca}_{10-x} \mathrm{Ni}_{x}\left(\mathrm{PO}_{4}\right)_{6}(\mathrm{OH})_{2}$.

Sorption of heavy metals on HAP has been extensively studied. It has previously shown by researchers that HAP had the greatest sorption capacity for $\mathrm{Pb}$ compared to other heavy metals and it could effectively immobilize $\mathrm{Pb}$ ions existing in the contaminated soils and waters (Lee et al., 2005; Smiciklas et al., 2008). High sorption capacity of HAP for $\mathrm{Pb}$ is due to the different dominant sorption mechanism for $\mathrm{Pb}$, dissolution- precipitation, whose driving force is rapid dissolution of HAP followed by precipitation of less soluble 
hydroxypyromorphite (HPy) (Mavropoulos et al., 2002; Zhang et al., 2010; Googerdchian et al., 2012).

In recent years, iron nanoparticles (INP), amongst other metallic nanoparticles; have received much attention for their potential application to the treatment of contaminated soils and waters. Their high surface area to volume ratio and high surface energy (Zhang et al.,1998) means that INP offer a greater reactivity than the surfaces of bulk scrap metal or iron filings/granules commonly used for remediation purposes in permeable reactive barriers, injection, etc., Tratynek (1996) and Bigg and Judd (2000) for reviews. The remediation mechanism depends on the nature of the contaminant but in all cases is driven by the oxidation of Fe (0) (Miehr et al., 2004).

To date, iron nanoparticles have been shown to be effective remediators of a range of contaminants including chlorinated organics (Nurmi et al., 2005; Kanel et al., 2005) and inorganic anions (Ponder et al. 2000; Zhu, 2010; Wijesinghe et al., 2014). In addition, INP have also been shown to successfully remediate solutions contaminated with a range of metals, including $\mathrm{Pb}, \mathrm{Cr}, \mathrm{Cu}$, As, Ni, Zn, Cd and Ag (Li and Zhang, 2007).

As the present results, $\mathrm{n}-\mathrm{ZVI}$ has high reactivity with contaminants such as $\mathrm{Pb}$ and $\mathrm{Ni}$ due to their high surface volume (Cantrell, and Kaplan, 1997 and Saleh et al., 2005). However, high reactivity alone is not enough to appoint this promising technology as a good in-situ remediation tool. Simultaneously, n-ZVI needs to be properly dispersed in water (Saleh et al., 2005).

\section{Batch sorption of Nano- hydroxyapatite and rice straw waste mixture}

The effect of rice straw waste and nano-hydroxyapatie as alone, and their mixture on removal percentage of $\mathrm{Pb}$ and $\mathrm{Ni}$ are presented in Table (9). Data showed that removal percentage of $\mathrm{Pb}$ increased as 21.48, 25.67 and $38.25 \%$ for rice straw waste (RSW), nano-hydroxyapatite (n-HAP), and their mixture (RSW+ n-HAP), respectively. The trend of Pb removal was 94.41, 99.67 and $99.69 \%$, respectively.

The results indicated maximum percentage removal of heavy metals was occurred on their mixture of nano- hydroxyapatite with rice straw waste for both $\mathrm{Pb}$ and $\mathrm{Ni}$. These results may be due to the many functional groups in RSW and $n$-HAP.

The removal percentage of $\mathrm{Pb}$ was more than of $\mathrm{Ni}$ indicated that the ability of $\mathrm{Pb}$ to bind with $\mathrm{RSW}$ or $\mathrm{n}-\mathrm{HAP}$ more than Ni. Explanation for this phenomenon may be due to the properties of the metal according to Marilen et al. (2007). Which could be due to larger ions might better binding site with two distinct active groups according to Figueiral et al (2000). 
Table (9). Effect of RSW, n-HAP and mixtures of n-HAP and RSW on percentage of $\mathrm{Ni}$ and $\mathrm{Pb}$ removal

\begin{tabular}{ccc}
\hline Treatment & \multicolumn{2}{c}{ Percentage Removal } \\
\cline { 2 - 3 } & $\mathbf{N i}^{+2}$ & $\mathbf{P b}^{\mathbf{+ 2}}$ \\
\hline Rice straw waste & 21.48 & 94.41 \\
Nano-hydroxyapatite & 25.67 & 99.67 \\
Rice straw waste + Nano-hydroxyapatite & 38.25 & 99.69 \\
\hline
\end{tabular}

Hannah and Thompson (2008) stated that the recent revolution of nanoscience and the advanced sophistication in the tools of characterization, shrinking the particle size of the sorbents is expected to influence the sorption capacity and further assist in developing commercial nanosorbents for wastewater treatment. In fact, nanotechnology has a significant impact to deal with legacy environmental pollution and to predict and prevent future environmental problems.

\section{ACKNOWLEDGEMENT}

The authors would like to thank progresses Fund of Science and Technological Development to assist in carrying out this research through the research work of the project entitled "Removal of heavy metals from El-Salam Canal by adsorption on some Sinai natural product in conjugation with nanomaterials".

\section{REFERENCES}

Acheampong, M. A., K. Pakshirajan, A. P. Annachhatre and P. N. L. Lens (2013). Removal of $\mathrm{Cu}$ (II) by onto coconut shell in fixed-bed column systems. J. Ind. Eng. Chem., 19: 841-848.

Afkhami, A., T. Madrakian, Z. Karimi and A. Amini (2007). Effect of treatment of carbon cloth with sodium hydroxide solution on its adsorption capacity for the adsorption of some cations, Colloids Surf., B., 304: 36-40.

Aissa, A., A. Abdeen and M. Abualreish (2014). Qualitative and quantitative analysis of phosphate rock from Hazm Al-jalamid area, northern Saudi Arabia. International Journal of Basic and Applied Sciences, 3(3): 190198.

Amini, M., H. Younesi and N. Bahramifar (2009). Statistical modeling and optimization of the cadmium biosorption process in an aqueous solution using Aspergillus niger, Colloids Surf. Physicochem. Eng. Aspects, 337: 67-73.

Aqeel, M., M. A. Ashraf, K. Mahmood and A. Wajid (2011). Study of low cost biosorbent for biosorption of heavy metals. Int.Conf.on Food Eng. and Biotechnology. IPCBEE vol.9. IACSIT Press, Singapoore.

Benguella, B. and $\mathbf{H}$. Benaissa (2002). Cadmium removal from aqueous solutions by chitin: kinetic and equilibrium studies, Water Res., 36 (10): 2463-2474. 
Bigg, T. and S. J. Judd (2000). Zero-valent iron for water treatment, Environ. Technol., 21: 661-670.

Cantrell, K. J. and D. L. Kaplan (1997). Zero-valent iron colloid emplacement in sand columns. J. Environ. Eng., 123: 499-505.

Chen, S. B., L. Chen and K. Xian (2010). Adsorption of aqueous $\mathrm{Cd} \mathrm{Pb}$ and $\mathrm{Cu}$ ions by nano-hydroxyapatite: Single- and multi-metal competitive adsorption study. Geochemical Journal, 44: $233-239$.

El-Sayed, G. O., H. A. Dessouki, S. S. Ibrahim (2010). Biosorption of Ni (II) and Cd (II) Ions From Aqueous Solutions Onto Rice Straw. Chemical Sciences Journal, CSJ-9

Eun, W. S. and R. M. Rowell (2005). Cadmium ion sorption onto lignocellulosic biosorbent modified by sulfonation: the origin of sorption capacity improvement. Chemosphere, 60(8):1054-1061.

Figueiral, M. M., B. Volesky, V. S. T. Ciminelli and F. A. Roddick (2000). Biosorption of metals in Brown seaweed Biomass, Elsevier Science, pergamon, Wat. Res. 34(1): 196

Gadd, G. M. (1992). Biosorption, J. Chem. Technol. Biotechnol, 55: 302-304.

Googerdchian, F., A. Moheb and R. Emadi (2012). Lead sorption properties of nanohydroxyapatite-alginate composite adsorbents. Chemical Engineering Journal, 200-202: 471-479.

Guo, Y., J. Qi, S.Yang, K. Yu, Z. Wang and H. Xu (2002). Adsorption of Cr (VI) on micro-and mesoporous rice husk-based activated carbon, J. Materials Chem. and Physics, 78: 132-137.

Gupta, V.K. and A. Rastogi (2008). Biosorption of lead (II) from aqueous solutions by non-living algal biomass Oedogoniumsp. andNostoc sp. - A comparative study. Colloids and Surfaces, B., 64: 170-178.

Hafiza, N. K., M. Hassan, N. Jamil, D. Ahmad, H. B. Fatima, K. Sara (2010) Biosorption of aqueous lead (II) on rice straws (oryza sativa) by flash column process. Journal of Scientific Research, Vol. XXXX No. 1.

Hannah, W. and P. B. Thompson (2008). Nanotechnology, risk and the environment: a review. J. Environ. Monit., 10:291-300.

Hassan, N. M., N. A. Mansour, M. Fayez-Hassan and E. Sedqy (2013). Elemental Analysis of Egyptian Phosphate Fertilizer Components Samples by TGA, DTA and IR Methods. IOSR Journal of Environmental Science, Toxicology and Food Technology (IOSR-JESTFT), 7(3): 98106.

Hayam, A.T. A. (2015) Removal of lead form industrial waste water using a low cost waste material. M.Sc.TH. The American University in Cairo, 1-148.

Holan, Z. R. and B. Volesky (1994). Biosorption of lead and nickel by biomass of marine algae. Biotechnology and Bioengineering, 43(11): 1001-1009.

Hui Gao, Y. Liu, G. Zeng, W. Xu, T. Li, W. Xi (2008). Characterization of heavy metals removal from aqueous solutions by a surplus agricultural waste Rice straw. Journal of Haz. Mat., 150: 446-452.

Jogi, M. M. and I. A. Ansari (2003). Non-conventional utilization of maize husk for the removal of iron from industrial wastewater, J. Biosci. \&Biotechnol. Res. Asia, 1: 63-66.

Kanel, S.R., B. Manning, L. Charlet and H. Choi (2005). Removal of arsenic (III) from groundwater by nanoscale zero-valent iron, Environ. Sci. Technol., 39: 1291-1298. 
Khalid, H. N., Mukhtar-ul-Hassan, N. Jamil, D. Ahmad, H. B. Fatima, S. Khatoon (2010). Biosorption of aqueous lead (II) on rice straws (Oriza sativa) by flash column process. Journal of Scientific Research, 40(1):18.

Khan, N. A., S. Ibrahim and P. Subramaniam (2004). Elimination of heavy metals from waste water using agricultural wastes as adsorbents. Malaysian J. of Science, 23: $43-51$.

Kumar, U. and M. Bandyopadhyay (2006). Sorption of cadmium from aqueous solution using pretreated rice husk. J. Biores. Technol., 97: 104109.

Lee, B. G. and R. M. Rowell (2004). Removal of heavy metal ions from aqueous solutions using lignocellulosic fibers. Journal of Natural Fibers, 1(1): 97-108.

Lee, C. K, H.S. Kim and J. H. Kwon (2005). The removal of heavy metals using hydroxyapatite, Environ. Eng. Res., 10: 205-212.

Lee, C. K., K. S. Low, and S. J. Mah, (1998). Removal of a gold (III) complex by quaterized rice husk", J.,Adv. Environ. Res., 2(3): 351- 359.

Li, X. Q., and W. X. Zhang (2007). Sequestration of metal cations with zero valent iron nanoparticles: a study with high resolution $\mathrm{X}$-ray photoelectron spectroscopy (HR-XPS), J. Phys. Chem., 111:6939-6946.

Ma, Q.Y., Traina, S.J., Logan, T.J., Ryan, J.A. (1994). Effects of aqueous Al, $\mathrm{Cd}, \mathrm{Cu}, \mathrm{Fe}(\mathrm{II}), \mathrm{Ni}$, and $\mathrm{Zn}$ on $\mathrm{Pb}$ immobilization by hydroxyapatite. Environmental Science \& Technology 28 (7), 1219e1228.

Marilen, M. P., S. T. Patricia, G. T. C. Ray, C. T. Lorele (2007). Biosorption of Copper, Cadmium and Lead by Copper-Resistant Bacteria Isolated from Mogpog River, Marinduque. Philippine Journal of Science, 136 (2): 155165

Martins, R.J.E., R. Pardo and R.A.R. Boaventura (2004). Cadmium(II) and zinc(II) adsorption by the aquatic moss Fontinalis antipyretica: effect of temperature, $\mathrm{pH}$ and water hardness. Water Res., 38: 693-699.

Mathew, F. (2008). Removal of heavy metals from electroplating wastewater using rice husk and coconut coir. M. Sc. In CHEMICAL ENGINEERING. MISSOURI UNIVERSITY OF SCIENCE AND TECHNOLOGY

Matlock, M.M., K.R. Henke and D.A. Atwood (2002). Effectiveness of commercial reagents for heavy metal removal from water with new insights for future chelate designs. J. Hazard. Mater., 92:129-142.

Matotte, L. S. (2007). IsoFit Documentation and User's Guide. Version 1.2. State University of New York at Buffalo, Department of Civil, Structural and Environmental Engineering

Mavropoulos, E., A. M. Rossi, A. M. Costa, C. A. Perez, J. C. Moreira, M. Saldanha (2002). Studies on the mechanisms of lead immobilization by hydroxyapatite. Environ. Sci. Technol., 36: 1625-1629.

Miehr, R., P. G. Tratnyek, J. Z. Bandstra, M. M. Scherer, M. Alowitz and E.J. Bylaska (2004). Diversity of contaminant reduction reactions by zero valent iron: role of the reductate, Environ. Sci. Technol. 38 (2004) 139147

Mobasherpour, I., E. Salahi and M. Pazouki (2011). Removal of nickel (II) from aqueous solutions by using nano-crystalline calcium hydroxyapatite. Journal of Saudi Chemical Society, 15: 105-112. 
Monteil Rivera, F. and M. Fedoroff (2002). Sorption of inorganic species on apatites from aqueous solutions. In: Encyclopedia of Surface and Colloid Science. Marcel Dekker, Inc., New York.

Nadeem, R., Zafar, M.N., Afzal, A., Hanif, V., Saeed, R. (2014). Potential of $\mathrm{NaOH}$ pretreated Mangifera indica waste biomass for the mitigation of $\mathrm{Ni}$ (II) and Co (II) from aqueous solutions. J. Taiwan Inst. Chem. Eng., 45: 967-972.

Nelson, R. L., P. K. Thor, and C. R. Heaton (1980). Rice straw buring: alternative policy implications. California Agriculture, 4-6.

Nurmi, J. T., P.G. Tratnyek, V. Sarathy, D.R. Baer, J.E. Amonette, K., C. Wang, J.C. Linehan, D.W. Matson, R.L. Penn and M.D. Driessen (2005). Characterization and properties of metallic iron nanoparticles: spectroscopy, electrochemistry, and kinetics, Environ. Sci. Technol., 39:1221-1230.

Nzihou, A. and P. Sharrock (2002). Calcium phosphate stabilization of fly ash with chloride extraction. Waste Manage., 2002, 235-239.

Pakshirajan, K. and Swaminathan, T. (2009). Biosorption of lead, copper, and cadmium by Phanerochaete chrysosporiumin ternary metal mixtures: Statistical analysis of individual and interaction effects. Appl. Biochem. Biotechnol., 158: 457-469.

Paulino, A.T., L.B. Santos and J. Nozaki (2008). Removal of $\mathrm{Pb}^{2+}, \mathrm{Cu}^{2+}$, and $\mathrm{Fe}^{3+}$ from battery manufacture wastewater by chitosan produced from silkworm chrysalides as a low-cost adsorbent. React. Funct. Polym., 68: 634-642.

Perez-Quintanilla, D., A. Sanchez, I. del Hierro, M. Fajardo and I. Sierra (2007). Preparation, characterization, and $\mathrm{Zn}^{2+}$ adsorption behavior of chemically modified MCM-41 with 5-mercapto-1-methyltetrazole, J. Colloid Interface Sci., 313: 551-562.

Ponder, S.M., J. G. Darab and T.E. Mallouk (2000). Remediation of Cr(VI) and $\mathrm{Pb}$ (II) aqueous solutions using supported, nanoscale zero-valent iron, Environ. Sci. Technol., 34: 2564-2569.

Rungrodnimitchai, S. and J. Dokbua (2006). Heavy metal ions absorbents from rice straw. In: Proceedings of the International Conference on Green and Sustainable Innovations, Chaing Mai, Thailand.

Safi, M. J., M. Bhagwanth Rao,1 K. S. P. Rao, and P. K. Govil (2006). Chemical analysis of phosphate rock using different methodsadvantages and disadvantages. X-Ray Spectrom, 35: 154-158.

Sakdaronnarong, C. and W. Jonglertjunya (2012). Rice straw and sugarcane bagasse degradation mimicking lignocellulose decay in nature: an alternative approach to biorefinery. Science Asia, 38:364-372.

Saleh, N., T. Phenrat, K. Sirk, B. Dufour, J. Ok, T. Sarbu, K. Matyjaszewski, R. D. Tilton, and G. V. Lowry (2005). Adsorbed triblock copolymers deliver reactive iron nanoparticles to the oil/water interface. Nano Lett., 5: 2489-2494.

Sari, A. and M. Tuzen (2008). Biosorption of cadmium (II) from aqueous solution by red algae (Ceramium virgatum): equilibrium, kinetic and thermodynamic studies, J. Hazard. Mater., 157: 448-454.

Sari, A., D. Mendil, M. Tuzen and M. Soylak (2008). Biosorption of Cd(II) and $\mathrm{Cr}$ (III) from aqueous solution by moss (Hylocomium splendens) biomass: equilibrium, kinetic and thermodynamic studies. Chem. Eng., J. 144:1-9. 
Sethuraman, P. and N. Balasubramanian (2010), Removal of $\mathrm{Cr}(\mathrm{VI})$ from aqueous solution using Bacillus subtilis, Pseudomonas aeruginosa and Enterobacter cloacae, International Journal of Engineering Science and Technology, 2(6):1811-1825.

Smiciklas, I., A. Onjia, S. Raicevic, K. Janackovic and M. Mitric (2008). Factors influencing the removal of divalent cations by hydroxyapatite, $\mathrm{J}$. Hazard. Mater., 152: 876-884.

Suemitsu, R., R. Venishi, I. Akashi and M. Nakano (1986). The Use of Dyestuff-treated Rice Hulls for Removal of Heavy Metals from Waste Water. Journal of Applied Polymer Science, 31: 75-83.

Tanaka, H., M. Futaoka, R. Hino, K. Kandori, and T. Ishikawa (2005). Structure of synthetic calcium hydroxyapatite particles modified with pyrophosphoric acid. J. Colloid Interface Sci., 283: 609-612.

Tratnyek, P.G. (1996). Putting corrosion to use: remediating contaminated groundwater with zero-valent metals, Chem. Ind-Lond., 13: 499-503.

Vieira. R.H. and B. Volesky, (2003). "Biosorption: A Solution to Pollution?". International Microbiology. 3:17-24.

Vijayaraghavan, K., K. Palanivelu and M. Velan (2006). Biosorption of Copper(II) and Cobalt(II) from Aqueous Solutions by Crab Shell Particles. Bioresource Technology, 97:1411-1419.

Volesky, B. (2000). Biosorption of Heavy Metals, CRC Press, Boca Raton, FL, 2000.

Volesky, B. and Z. R. Holan (2008). Biosorption of heavy metals. Biotechnology and Bioengineering, 11:235-250.

Wagner, N. J. and R.J. Jula (1981). Activated carbon adsorption, in: J.R. Perrich (Ed.), Activated Carbon Adsorption, CRC Press, Boca-Raton, FL, 1981.

Wijesinghe, W.P.S.L. (2014). Overview to hydroxyapatite nanoparticles and their applications. Sciscitator. Vol 01.

Wong, K. K, C. K. Lee, K.S. Low, M. J. Haron (2003). Removal of Cu and Pb by Tartaric Acid Modified Rice Husk from Aqueous Solution. Chemosphere, 50: 23-28.

Yuan, F, G. Ji-Lai, G. Zeng, Q. Niu, H. Zhang, C.Niu and J. Deng (2010). Adsorption of $\mathrm{Cd}$ (II) and Zn (II) from aqueous solutions using magnetic hydroxyapatite nanoparticles as adsorbents Chemical Engineering Journal, 162: 487-494.

Zhang, W. X., C. B. Wang and H. L. Lien (1998). Treatment of chlorinated organic contaminants with nanoscale bimetallic particles, Catal. Today, 40: 387-395.

Zhang, Z., M. Li, W. Chen, S. Zhu, N. Liu and L. Zhu (2010). Immobilization of lead and cadmium from aqueous solution and contaminated sediment using nanohydroxyapatite, Environ. Pollut., 158: 514-519.

Zhu, W. (2010). Experimental study on the conduction function of nanohydroxyapatite artificial bone. Micro Nano Lett., 5: 19-27. 


\section{الملخص العربي}

\section{إزالة بعض العناصر الثقيلة باستخدام مواد الادمصاص الحيوى والحبيبات النانوية}

$$
\begin{aligned}
& \text { دعاء أحمد النجار' - جمال عبد الناصر خليل' - ثناء إبراهيم شلبيج - عزة رشاد أحمد' - } \\
& \text { وفاء حسن عليخ } \\
& \text { ا قسم تحسين التربة - معهد بحوث الأراضي والمياه والبيئة - مركز البحوث الزراعية - القاهرة } \\
& \text { r قسم الأراضي والكيمياء الزراعية - كلية الزراعة (سابا باشا)- جامعة الاسكندرية } \\
& \text { r قسم الفيزياء الحيوية الطبية - معهد البحوث الطبية - جامعة الاسكندرية }
\end{aligned}
$$

أجريت تجارب الادمصاص لدراسة دور مواد الادمصاص الحيوى والحبيبات النانوية لازالة بعض العناصر النقيلة (الرصاص والنيكل) من المحاليل المائية ـ استخدم فش الارز كمادة ادمصاص حيوية ( نوائج العمليات الزراعية) .

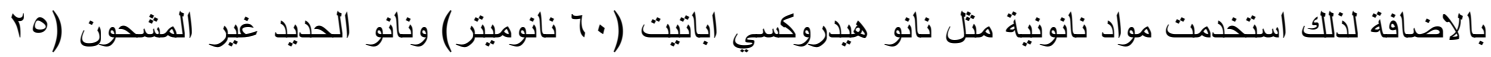

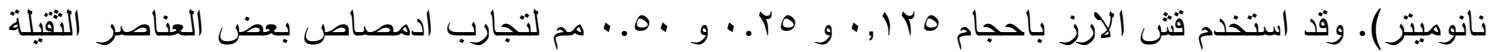

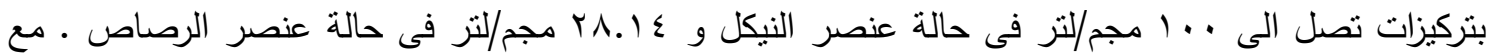
المواد النانونية وكذللك مسحوق صخر الفوسفات (זT ... مم)، أوضحت النتائج ان قش الارز بحجم هب .. دم

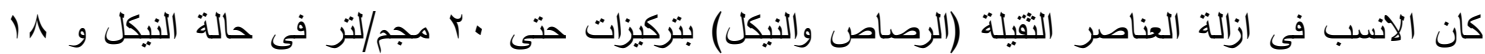
مجم/ليتر فى حالة الرصاص وهذا يرجع اللى القابلية العالية للمواد النانوية لادمصاص العناصر النقيلة كما أوضحته نماذج الادمصاص الخطيي ونموذج فريندليش. كذللك اوضحت النتائج القدرة العالية لحبيات الهيدروكسي لهي لاديه اباتيت النانونية مع قش الآرز لادمصاص الرصاص والنيكل وهذا قد يعود الى المجاميع الفعالة فى قش الارز والحبيبات النانونية ـ كما ان خليط قش الارز وحبيبات الهيدروكسي اباتيت النانونية كانت ذات قدرة لانية عالية

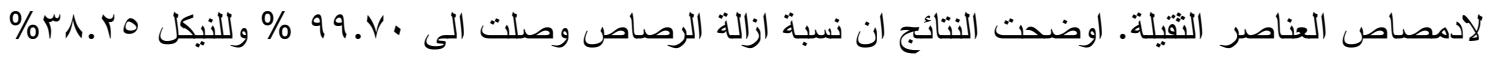
وهذا يوضح قدرة الرصاص العالية للارتباط بقش الارز وحبيبات الهيدروكسي أباتيت النانونية . النتائج الحالية مفيدة جدا فى معالجة المياه العادمة ( مثل مياه الصرف الصناعي ومياه الصرف الزراعي) وازالة العناصر التقيلة وجعلها

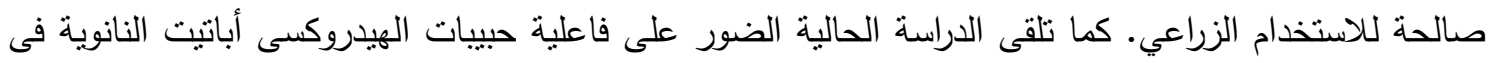
ازالة أيونات الرصاص والنيكل من المحاليل المائية ومعالجة المباه العادمة. وتوصى الدراسة بعمل دراسات مستقبلية لمعرفة دور المواد النانوية فى ازالة العناصر الثقيلة المختلفة من المياه العادمة مختلفة المصدر . 
